\title{
Small but mighty: old and new parvoviruses of veterinary significance
}

\author{
Mason C. Jager, Joy E. Tomlinson, Robert A. Lopez-Astacio, Colin R. Parrish and Gerlinde R. Van de Walle* (D)
}

\begin{abstract}
In line with the Latin expression "sed parva forti" meaning "small but mighty," the family Parvoviridae contains many of the smallest known viruses, some of which result in fatal or debilitating infections. In recent years, advances in metagenomic viral discovery techniques have dramatically increased the identification of novel parvoviruses in both diseased and healthy individuals. While some of these discoveries have solved etiologic mysteries of well-described diseases in animals, many of the newly discovered parvoviruses appear to cause mild or no disease, or disease associations remain to be established. With the increased use of animal parvoviruses as vectors for gene therapy and oncolytic treatments in humans, it becomes all the more important to understand the diversity, pathogenic potential, and evolution of this diverse family of viruses. In this review, we discuss parvoviruses infecting vertebrate animals, with a special focus on pathogens of veterinary significance and viruses discovered within the last four years.
\end{abstract}

Keywords: Pathogenicity, Animal parvoviruses, Viral therapeutics, Viral metagenomics, Amdoparvovirus, Copiparvovirus, Chaphamaparvovirus

\section{Background}

While diseases caused by viruses in the Family Parvoviridae have been known since the early twentieth century, the properties of these viruses were only revealed in the 1960s. High-throughput sequencing and new metagenomic analytical methods have greatly increased the number of new parvoviruses discovered in animals in recent years (Fig. 1, Table 1). For example, a recent DNA-sequencing virome study using feces collected from Australian ducks identified and characterized 46 different parvoviruses belonging to three different genera [1]. However, many of the recently discovered viruses are poorly understood beyond their DNA sequence. An added challenge in host assignment of novel viruses is that viral DNA detected in feces could originate from the animal or from its diet, as seen with the initial identification of tilapia parvovirus in the feces of a crocodile [2].

\footnotetext{
*Correspondence: grv23@cornell.edu
}

Baker Institute for Animal Health, College of Veterinary Medicine, Cornell University, Ithaca, NY 14853, USA
Finding viral DNA or virus in the tissues or blood of an animal provides greater certainty of the source of DNA.

Many of these newly discovered viruses are likely part of the complex virome of their host species, and cause little or no disease, while others may be pathogens causing diseases for which an etiological agent has not previously been identified. Also, most parvoviruses likely cause little or no disease in immune competent hosts and the few that are consistently associated with disease appear to be the exception (Fig. 2). Examples of recently identified pathogenic parvoviruses in vertebrate animals include equine parvovirus-hepatitis (EqPV-H), tilapia parvovirus (TiPV), mouse kidney parvovirus (MKPV), and red panda parvovirus (RpPV) [3-10] (Fig. 3). EqPV-H and MKPV represent new parvoviruses associated with longrecognized conditions, whereas TiPV, and possibly RpPV, are of emerging concern.

In situ hybridization (ISH) has been an important tool in identifying disease association of these newly discovered parvoviruses by demonstrating the presence of parvoviral nucleic acids (NA) in lesions $[4-7,10,11]$. This technology, which has been available for decades, has original author(s) and the source, provide a link to the Creative Commons licence, and indicate if changes were made. The images or other third party material in this article are included in the article's Creative Commons licence, unless indicated otherwise in a credit line to the material. If material is not included in the article's Creative Commons licence and your intended use is not permitted by statutory regulation or exceeds the permitted use, you will need to obtain permission directly from the copyright holder. To view a copy of this licence, visit http://creativecommons.org/licenses/by/4.0/. The Creative Commons Public Domain Dedication waiver (http://creativeco mmons.org/publicdomain/zero/1.0/) applies to the data made available in this article, unless otherwise stated in a credit line to the data. 


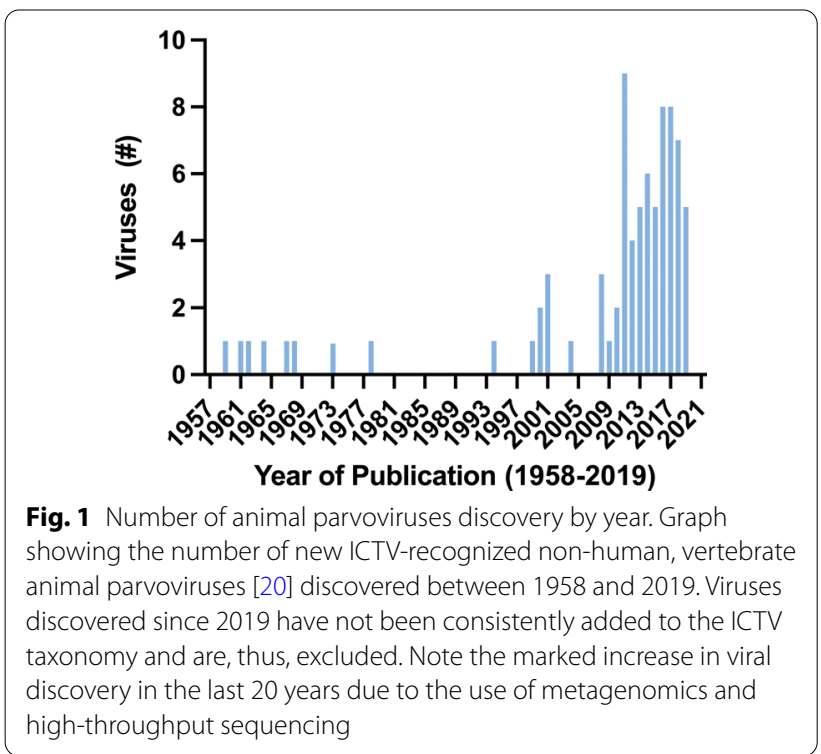

recently been made more accessible through commercialization and rapid probe development. Probes can be designed and produced within weeks after a partial genome sequence is obtained (in contrast to antibody production for immunohistochemistry (IHC) which takes months) [12]. Importantly, ISH allows the use of a modified form of Koch's postulates that was developed in 1996-which states that viral NA sequence should be present within lesions, and thus addresses problems with the classical postulates first developed by Robert Koch and Friedrich Loeffler in 1884, which require isolating, reinfecting, and re-isolating pathogens [13]. As many recently discovered parvoviruses have yet to be isolated from culture, including ISH as a more widely used tool will illuminate the clinical relevance of many of these viruses. Furthermore, experimental infections of freeranging or endangered species, such as the sea otter or red panda, are not feasible and preclude establishing disease associations for novel viruses through experimental infection studies. Throughout this review, we will present and evaluate the available evidence for pathogenicity of select novel parvoviruses using these guidelines (Table 2).

\section{General features of parvoviruses}

Since the mechanisms of parvovirus replication, genome organization, and structure, have been recently and extensively reviewed elsewhere [14-18], we will only briefly summarize these specific features.

\section{Taxonomy}

The Parvoviridae family was originally divided into two subfamilies of viruses that infect either invertebrate (Densovirinae) or vertebrate (Parvovirinae) hosts, and these subfamilies were then further divided into genera based on their genome organization and amino acid (aa) identity of viral proteins [14]. Viruses are considered members of the same species if their non-structural (NS) proteins share more than $85 \%$ aa sequence identity, while diverging greater than $15 \%$ from members of other genera $[14,19,20]$. This classification was recently challenged by the discovery of vertebrate parvoviruses, identified via metagenomic sampling of animal feces and named chapparvoviruses, that are more closely related to viruses in the Densovirinae subfamily than to those in the Parvovirinae subfamily [20]. The International Committee on Taxonomy of Viruses (ICTV) recently split the Densovirinae subfamily further into the Densovirinae and Hamaparvovirinae subfamilies. The latter includes five genera, with the genus Chaphamaparvovirus covering these formerly unclassified chapparvoviruses. This new subfamily is characterized by an average of $30 \%$ aa sequence identity of their NS1 protein and all species lack the otherwise conserved phospholipase $\mathrm{A}_{2}$ domain in the surface viral protein (VP) [20]. Also, parvoviruses can be classified in the same genus if their complete NS1 protein sequence clusters in a monophyletic lineage at the subfamily level, and likewise, for their super family 3 (SF3) helicase domains at the family level [20]. In addition to classification based on genome organization and/ or aa sequence identity, parvoviruses can also be classified functionally into either autonomous parvoviruses or dependoparvoviruses, based on their ability to complete their replication cycle independently or their dependence on coinfection with another DNA virus to successfully replicate, respectively.

\section{Genome organization and major proteins}

While differences exist in the presence of accessory proteins, most autonomous parvoviruses are shown as having a genome structure with the large NS open reading frame (ORF) on the "left" and the VP ORF on the "right" (Fig. 3). The genome termini contain short, imperfect palindromic sequences or inverted terminal repeats (ITRs) that form varying secondary structures, which create self-priming palindromic hairpin telomeres that function as viral DNA replication origins [14]. These secondary structures can either be the same or different at the 5'- and 3'-termini, leading to homotelomeric or heterotelomeric genomes, respectively, and are consistent across a genus. Homotelomeric viruses package equal numbers of plus or minus stranded genomes in viral particles. A packaging bias toward one viral genome strand is observed in parvoviruses with heterotelomeric genomes [21-23].

The NS gene (Rep in adeno-associated viruses (AAVs) of the genus Dependoparvovirus) forms one or more 
Table 1 Summary of vertebrate animal parvoviruses by genus and species. Vertebrate animal parvoviruses from the ten genera of subfamily Parvovirinae and the genus Chaphamaparvovirus of subfamily Hamaparvovirinae are listed alphabetically by species, as proposed by the ICTV [20]

\begin{tabular}{|c|c|c|c|c|c|c|}
\hline Genus & Species & Virus name & Abbrev & Tissue source & Age affected & References \\
\hline \multirow[t]{7}{*}{ Amdoparvovirus } & $\begin{array}{l}\text { Carnivore amdoparvovi- } \\
\text { rus } 1\end{array}$ & $\begin{array}{l}\text { Aleutian mink disease } \\
\text { parvovirus }\end{array}$ & ADV & Tissue & Young/adult & [44] \\
\hline & $\begin{array}{l}\text { Carnivore amdoparvovi- } \\
\text { rus } 2\end{array}$ & Gray fox parvovirus & GFAV & S, Lu & Unknown & [98] \\
\hline & $\begin{array}{l}\text { Carnivore amdoparvovi- } \\
\text { rus } 3\end{array}$ & $\begin{array}{l}\text { Racoon dog and fox } \\
\text { amdoparvovirus }\end{array}$ & RFAV & $\mathrm{S}, \mathrm{K}, \mathrm{MLN}$, blood & Young & [88] \\
\hline & $\begin{array}{l}\text { Carnivore amdoparvovi- } \\
\text { rus } 4\end{array}$ & Skunk amdoparvovirus & SKAV & Tissue & Young/adult & [89] \\
\hline & $\begin{array}{l}\text { Carnivore amdoparvovi- } \\
\text { rus } 5\end{array}$ & $\begin{array}{l}\text { Red panda amdoparvo- } \\
\text { virus }\end{array}$ & RpAPV & S, Li, Lu, K, SI, feces & Unknown & [10] \\
\hline & NA & $\begin{array}{l}\text { Labrador amdoparvovi- } \\
\text { rus } 1\end{array}$ & LaAV-1 & $\mathrm{S}, \mathrm{LN}$, muscle & Unknown & [74] \\
\hline & NA & $\begin{array}{l}\text { Labrador amdoparvovi- } \\
\text { rus } 2\end{array}$ & LaAV-2 & S, LN, muscle & Unknown & [74] \\
\hline Artiparvovirus & $\begin{array}{l}\text { Chiropteran artiparvovi- } \\
\text { rus } 1\end{array}$ & $\begin{array}{l}\text { Artibeus jamaicensis } \\
\text { parvovirus }\end{array}$ & Aj-BtPV-1 & Blood & Unknown & [99] \\
\hline \multirow[t]{3}{*}{ Aveparvovirus } & Columbid aveparvovirus 1 & Pigeon parvovirus 1 & PiPV1 & Feces & Unknown & [125] \\
\hline & Galliform aveparvovirus 1 & $\begin{array}{l}\text { Turkey parvovirus } \\
\text { Chicken parvovirus }\end{array}$ & $\begin{array}{l}\text { TuPV } \\
\text { ChPV }\end{array}$ & । & Unknown & [346] \\
\hline & Gruiform aveparvovirus 1 & $\begin{array}{l}\text { Red-crowned crane } \\
\text { parvovirus }\end{array}$ & RcPV & Feces & Unknown & [127] \\
\hline \multirow[t]{22}{*}{ Bocaparvovirus } & Carnivore bocaparvovirus 1 & Minute virus of canines & MVC & Feces & Young & [133] \\
\hline & Carnivore bocaparvovirus 2 & Canine bocavirus 2 & CBoV2 & Respiratory & Unknown & [152] \\
\hline & NA & Canine bocavirus 3 & CBoV3 & $\mathrm{Li}$ & Unknown & [155] \\
\hline & Carnivore bocaparvovirus 3 & Feline bocavirus 1 & FBoV1 & $\begin{array}{l}\text { Feces, blood, K, nasal } \\
\text { swabs }\end{array}$ & Unknown & 144[ \\
\hline & Carnivore bocaparvovirus 4 & Feline bocaparvovirus 2 & FboV2 & Feces & Unknown & [145] \\
\hline & Carnivore bocaparvovirus 5 & Feline bocaparvovirus 3 & FBoV3 & Feces & Unknown & [146] \\
\hline & Carnivore bocaparvovirus 6 & Mink bocavirus 1 & MiBoV1 & Feces & Unknown & [167] \\
\hline & $\begin{array}{l}\text { Chiopteran bocaparvo- } \\
\text { virus } 1\end{array}$ & $\begin{array}{l}\text { Myotis myotis (bat) } \\
\text { bocavirus } 1\end{array}$ & BtBoV1 & $\begin{array}{l}\text { Pharyngeal and anal } \\
\text { swabs }\end{array}$ & Unknown & [161] \\
\hline & $\begin{array}{l}\text { Chiopteran bocaparvo- } \\
\text { virus } 2\end{array}$ & Bat bocavirus WM40 & BtBoVwm40 & Tissue & Unknown & [162] \\
\hline & $\begin{array}{l}\text { Chiopteran bocaparvo- } \\
\text { virus } 3\end{array}$ & Bat bocavirus XM30 & BtBoVxm30 & Tissue & Unknown & [162] \\
\hline & $\begin{array}{l}\text { Chiopteran bocaparvo- } \\
\text { virus } 4\end{array}$ & $\begin{array}{l}\text { Miniopterus schreibersii } \\
\text { bat bocavirus }\end{array}$ & BtBoV2 & S, Lu, I & Unknown & [163] \\
\hline & $\begin{array}{l}\text { Chiopteran bocaparvo- } \\
\text { virus } 5\end{array}$ & $\begin{array}{l}\text { Rousettus leschenaultii } \\
\text { bocaparvovirus } 1\end{array}$ & RIBoV & $S, L i, I$ & Unknown & [164] \\
\hline & $\begin{array}{l}\text { Lagomorph bocaparvo- } \\
\text { virus } 1\end{array}$ & Rabbit bocaparvovirus & RBoV & Feces & Unknown & [168] \\
\hline & Pinniped bocaparvovirus 1 & $\begin{array}{l}\text { California sea lion bocavi- } \\
\text { rus } 1\end{array}$ & CslBoV1 & Feces & Unknown & [169] \\
\hline & Pinniped bocaparvovirus 2 & $\begin{array}{l}\text { California sea lion bocavi- } \\
\text { rus } 3\end{array}$ & CslBov3 & Feces & Unknown & [169] \\
\hline & Primate bocaparvovirus 1 & Human bocavirus 1 and 3 & HBoV1, 3 & Respiratory & Young & [128] \\
\hline & Primate bocaparvovirus 2 & Human bocavirus 2 and 4 & $\mathrm{HBoV} 2,4$ & Stool & Unknown & [347] \\
\hline & Primate bocaparvovirus 3 & $\begin{array}{l}\text { Macca mulatta bocapar- } \\
\text { vovirus }\end{array}$ & MmBoV & Feces & Unknown & [348] \\
\hline & Rodent bocaparvovirus 1 & Rat bocavirus & RBoV & $L u, I, S, K$ & Unknown & [164] \\
\hline & Rodent bocaparvovirus 2 & Murine bocavirus & MuBoV & Feces & Unknown & [223] \\
\hline & Ungulate bocaparvovirus 1 & Bovine parvovirus 1 & BPV1 & । & Young & [140] \\
\hline & Ungulate bocaparvovirus 2 & Porcine bocavirus 1 & PBoV1 & LN & Unknown & [156] \\
\hline
\end{tabular}


Table 1 (continued)

\begin{tabular}{|c|c|c|c|c|c|c|}
\hline Genus & Species & Virus name & Abbrev & Tissue source & Age affected & References \\
\hline & Ungulate bocaparvovirus 3 & Porcine bocavirus SX & PBoVsx & Serum & Unknown & [349] \\
\hline & Ungulate bocaparvovirus 4 & Porcine bocavirus $\mathrm{H} 18$ & PBoVh18 & Feces & Unknown & [159] \\
\hline & Ungulate bocaparvovirus 5 & Porcine bocavirus 3 & PBoV3 & Feces & Unknown & [350] \\
\hline & Ungulate bocaparvovirus 6 & Bovine bocaparvovirus 2 & BBoV2 & Nasal swab & Unknown & [143] \\
\hline & Ungulate bocaparvovirus 7 & $\begin{array}{l}\text { Dromedary camel boca- } \\
\text { parvovirus } 1\end{array}$ & DBoV1 & Feces & Unknown & {$[165]$} \\
\hline & Ungulate bocaparvovirus 8 & $\begin{array}{l}\text { Dromedary camel boca- } \\
\text { parvovirus } 2\end{array}$ & DBoV2 & Feces & Unknown & {$[165]$} \\
\hline & Ungulate bocaparvovirus 9 & $\begin{array}{l}\text { Vicugna pacos bocapar- } \\
\text { vovirus }\end{array}$ & VpBoV & Feces & Unknown & {$[351]$} \\
\hline \multirow[t]{12}{*}{ Copiparvovirus } & Pinniped copiparvovirus 1 & Sesavirus & SesaV & Feces & Unknown & [199] \\
\hline & Ungulate copiparvovirus 1 & Bovine parvovirus 2 & BPV2 & Serum & Unknown & [180] \\
\hline & Ungulate copiparvovirus 2 & Porcine parvovirus 4 & PPV4 & Lu lavage & Unknown & {$[170]$} \\
\hline & Ungulate copiparvovirus 3 & Roe deer copiparvovirus & RdPV & Ixodes tick & Unknown & [198] \\
\hline & Ungulate copiparvovirus 4 & Porcine parvovirus 6 & PPV6 & Fetus & Unknown & [194] \\
\hline & Ungulate copiparvovirus 5 & Bosavirus & BosaV & Serum & Unknown & [181] \\
\hline & Ungulate copiparvovirus 6 & $\begin{array}{l}\text { Equine parvovirus- } \\
\text { hepatitis }\end{array}$ & EqPV-H & Li, serum & Adult & [3] \\
\hline & NA & Equine parvovirus-CSF & EqPV-CSF & CSF & Unknown & [196] \\
\hline & NA & Equine copiparvovirus & EqCoPV & Plasma & Unknown & [178] \\
\hline & NA & Sheep copiparvovirus & Sheep PV & Serum & Unknown & [200] \\
\hline & $\begin{array}{l}\text { Adeno-associated } \\
\text { dependoparvovirus A }\end{array}$ & $\begin{array}{l}\text { Adeno-associated virus } \\
1,2,3,4\end{array}$ & AAV1-4 & Cell culture & Unknown & {$[202]$} \\
\hline & $\begin{array}{l}\text { Adeno-associated } \\
\text { dependoparvovirus B }\end{array}$ & Adeno-associated virus 5 & AAV5 & Cell culture & Unknown & [352] \\
\hline \multirow[t]{9}{*}{ Dependoparvovirus } & $\begin{array}{l}\text { Anseriform dependopar- } \\
\text { vovirus } 1\end{array}$ & $\begin{array}{l}\text { Goose parvovirus } \\
\text { Muscovy duck parvovirus } \\
\text { Novel goose parvovirus }\end{array}$ & $\begin{array}{l}\text { GPV } \\
\text { MDPV } \\
\text { nGPV }\end{array}$ & $\begin{array}{l}\text { Tissue } \\
\text { Tissue } \\
\text { Li, S, heart }\end{array}$ & $\begin{array}{l}\text { Young } \\
\text { Young } \\
\text { Young }\end{array}$ & $\begin{array}{l}{[204]} \\
{[209]} \\
{[353]}\end{array}$ \\
\hline & Avian dependoparvovirus 1 & $\begin{array}{l}\text { Avian adeno-associated } \\
\text { virus }\end{array}$ & AAAV & Respiratory & Unknown & {$[215]$} \\
\hline & $\begin{array}{l}\text { Carnivore dependoparvo- } \\
\text { virus } 1\end{array}$ & Feline dependoparvovirus & FdPV & Feces & Unknown & [151] \\
\hline & $\begin{array}{l}\text { Chiropteran dependopar- } \\
\text { vovirus } 1\end{array}$ & $\begin{array}{l}\text { Bat adeno-associated } \\
\text { virus }\end{array}$ & BtAAV & Feces & Unknown & [219] \\
\hline & $\begin{array}{l}\text { Pinniped dependoparvo- } \\
\text { virus } 1\end{array}$ & $\begin{array}{l}\text { California sea lion adeno- } \\
\text { associated virus } 1\end{array}$ & CSIAAV1 & Feces & Unknown & [169] \\
\hline & $\begin{array}{l}\text { Rodent dependoparvo- } \\
\text { virus } 1\end{array}$ & $\begin{array}{l}\text { Murine adeno-associated } \\
\text { virus } 1\end{array}$ & MAAV1 & Feces & Unknown & [223] \\
\hline & $\begin{array}{l}\text { Rodent dependoparvo- } \\
\text { virus } 2\end{array}$ & $\begin{array}{l}\text { Murine adeno-associated } \\
\text { virus } 2\end{array}$ & MAAV2 & Feces & Unknown & [223] \\
\hline & $\begin{array}{l}\text { Squamate dependopar- } \\
\text { vovirus } 1\end{array}$ & $\begin{array}{l}\text { Snake adeno-associated } \\
\text { virus }\end{array}$ & SAAV & Heart, S, Li, K & Unknown & [224] \\
\hline & $\begin{array}{l}\text { Squamate dependopar- } \\
\text { vovirus } 2\end{array}$ & $\begin{array}{l}\text { Bearded dragon parvo- } \\
\text { virus }\end{array}$ & BDPV & Lu, Li, I, K, gonads & Unknown & {$[227]$} \\
\hline \multirow[t]{7}{*}{ Erythroparvovirus } & $\begin{array}{l}\text { Pinniped erythroparvo- } \\
\text { virus } 1\end{array}$ & Seal parvovirus & SePV & Brain & Unknown & {$[235]$} \\
\hline & Primate erythroparvovirus 1 & Human parvovirus B19 & B19V & Serum & Young/Adult & [354] \\
\hline & Primate erythroparvovirus 2 & Simian parvovirus & SPV & Serum & Young/Adult & [53] \\
\hline & Primate erythroparvovirus 3 & $\begin{array}{l}\text { Rhesus macaque parvo- } \\
\text { virus }\end{array}$ & RmPV & Serum & Unknown & [232] \\
\hline & Primate erythroparvovirus 4 & $\begin{array}{l}\text { Pig-tailed macaque } \\
\text { parvovirus }\end{array}$ & PmPV & Serum & Unknown & [232] \\
\hline & Rodent erythroparvovirus 1 & Chipmunk parvovirus & ChpPV & Serum & Unknown & [233] \\
\hline & $\begin{array}{l}\text { Ungulate erythroparvo- } \\
\text { virus } 1\end{array}$ & Bovine parvovirus 3 & $\mathrm{BPV} 3$ & Serum & Unknown & [180] \\
\hline
\end{tabular}


Table 1 (continued)

\begin{tabular}{|c|c|c|c|c|c|c|}
\hline Genus & Species & Virus name & Abbrev & Tissue source & Age affected & References \\
\hline Loriparvovirus & Primate loriparvovirus 1 & Slow loris parvovirus 1 & SI.L-PV-1 & I, Li, K, Lu, Serum & Unknown & [237] \\
\hline \multirow[t]{15}{*}{ Protoparvovirus } & Carnivore protoparvovirus 1 & $\begin{array}{l}\text { Canine parvovirus } \\
\text { Feline panleukopenia } \\
\text { virus }\end{array}$ & $\begin{array}{l}\text { CPV-2 } \\
\text { FPV }\end{array}$ & $\begin{array}{l}\text { Feces } \\
\mathrm{S}\end{array}$ & $\begin{array}{l}\text { Young } \\
\text { Young }\end{array}$ & $\begin{array}{l}{[260]} \\
{[241]}\end{array}$ \\
\hline & Carnivore protoparvovirus 2 & Sea otter parvovirus & SoPV & MLN, Li, Lu, S & Unknown & [285] \\
\hline & Carnivore protoparvovirus 3 & Canine bufavirus & CBuV & Feces, NP swabs & Unknown & [286] \\
\hline & Carnivore protoparvovirus 4 & Fox parvovirus & FoPV & Feces & Unknown & [292] \\
\hline & $\begin{array}{l}\text { Chiopteran protoparvo- } \\
\text { virus } 1\end{array}$ & Megabat bufavirus 1 & BtBuV1 & $\mathrm{S}$, feces & Unknown & [355] \\
\hline & $\begin{array}{l}\text { Eulipotyphala protopar- } \\
\text { vovirus } 1\end{array}$ & $\begin{array}{l}\text { Mpulungu (shrew] } \\
\text { bufavirus }\end{array}$ & MpBuV & $S$, feces & Unknown & {$[356]$} \\
\hline & Primate protoparvovirus 1 & Bufavirus & BuV & Feces & Unknown & {$[357]$} \\
\hline & Primate protoparvovirus 2 & $\begin{array}{l}\text { Wuharv (rhesus) parvo- } \\
\text { virus } 1\end{array}$ & WuBuV1 & Feces & Unknown & [358] \\
\hline & Primate protoparvovirus 3 & Cutavirus & CutaV & Feces & Unknown & [359] \\
\hline & Primate protoparvovirus 4 & Tusavirus & TuV & Feces & Unknown & {$[360]$} \\
\hline & Rodent protoparvovirus 1 & Minute virus of mice & MVM & Serum & Young & {$[272]$} \\
\hline & Rodent protoparvovirus 2 & Rat parvovirus 1 & RPV1 & Tumor & Young & [280] \\
\hline & Rodent protoparvovirus 3 & Rat bufavirus SY-2015 & RatBuV & I content & Unknown & [334] \\
\hline & Ungulate protoparvovirus 1 & Porcine parvovirus & PPV & Fetal tissues & Young & [268] \\
\hline & Ungulate protoparvovirus 2 & $\begin{array}{l}\text { Porcine bufavirus } \\
\text { protoparvovirus [porcine) }\end{array}$ & PBuV & Feces & Unknown & [294] \\
\hline \multirow[t]{6}{*}{ Tetraparvovirus } & $\begin{array}{l}\text { Chiropteran tetraparvo- } \\
\text { virus } 1\end{array}$ & $\begin{array}{l}\text { Eidolon helvum (bat) } \\
\text { parvovirus } 1\end{array}$ & BtPARV4 & Blood & Unknown & [99] \\
\hline & Primate tetraparvovirus 1 & Human parvovirus 4 & PARV4 & Plasma & Unknown & [300] \\
\hline & Ungulate tetraparvovirus 1 & Bovine hokovirus 1 & BPARV4 & S & Unknown & [308] \\
\hline & Ungulate tetraparvovirus 2 & $\begin{array}{l}\text { Porcine hokovirus/Porcine } \\
\text { parvovirus } 3\end{array}$ & PPARV4/PPV3 & $L N$, Li, serum, feces & Unknown & [308] \\
\hline & Ungulate tetraparvovirus 3 & $\begin{array}{l}\text { Porcine parvovirus } 2 \\
\text { Parvovirus YX-2010/CHN }\end{array}$ & PPV2 & Serum & Unknown & [301] \\
\hline & Ungulate tetraparvovirus 4 & Ovine hokovirus 1 & OvPARV4 & $\mathrm{Li}, \mathrm{S}$ & Unknown & [311] \\
\hline \multicolumn{7}{|c|}{ Chaphamaparvovirus } \\
\hline & $\begin{array}{l}\text { Carnivore chaphamapar- } \\
\text { vovirus } 1\end{array}$ & Cachavirus 1 and 2 & CachaV-1 & Feces & Unknown & [322] \\
\hline & $\begin{array}{l}\text { Carnivore chaphamapar- } \\
\text { vovirus } 2\end{array}$ & Fechavirus & FChPV & Feces & Unknown & {$[151]$} \\
\hline & $\begin{array}{l}\text { Chiropteran chaphama- } \\
\text { parvovirus } 1\end{array}$ & $\begin{array}{l}\text { Desmodus rotundus } \\
\text { chapparvovirus }\end{array}$ & DrPV-1 & K & Unknown & {$[331]$} \\
\hline & $\begin{array}{l}\text { Dasyurid chaphamaparvo- } \\
\text { virus 1-3 }\end{array}$ & $\begin{array}{l}\text { Tasmanian devil-associ- } \\
\text { ated chapparvovirus 1,2, } \\
\text { and } 6\end{array}$ & TdChPV & Feces & Unknown & [332] \\
\hline & $\begin{array}{l}\text { Galliform chaphamapar- } \\
\text { vovirus } 1\end{array}$ & Turkey parvovirus 2 & TPV2 & Feces & Unknown & {$[326]$} \\
\hline & $\begin{array}{l}\text { Galliform chaphamapar- } \\
\text { vovirus } 2\end{array}$ & Chicken chapparvovirus 2 & ChikPV2 & । & Unknown & {$[327]$} \\
\hline & $\begin{array}{l}\text { Galliform chaphamapar- } \\
\text { vovirus } 3\end{array}$ & $\begin{array}{l}\text { Chicken chapparvovirus } \\
\text { HK }\end{array}$ & & & & [327] \\
\hline & $\begin{array}{l}\text { Galliform chaphamapar- } \\
\text { vovirus } 4\end{array}$ & Peafowl parvovirus 1 & PePV1 & Li, l, heart, stomach & Unknown & [329] \\
\hline & $\begin{array}{l}\text { Galliform chaphamapar- } \\
\text { vovirus } 5\end{array}$ & Peafowl parvovirus 2 & PePV2 & Li, I, heart, stomach & Unknown & {$[329]$} \\
\hline & $\begin{array}{l}\text { Primate chaphamaparvo- } \\
\text { virus } 1\end{array}$ & $\begin{array}{l}\text { Capuchin kidney parvo- } \\
\text { virus }\end{array}$ & CKPV & K & Unkown & [8] \\
\hline & $\begin{array}{l}\text { Psittacine chaphamapar- } \\
\text { vovirus } 1\end{array}$ & $\begin{array}{l}\text { Psittacara leucophthalmus } \\
\text { chapparvovirus }\end{array}$ & PIChPV & Feces & Unknown & {$[328]$} \\
\hline
\end{tabular}


Table 1 (continued)

\begin{tabular}{|c|c|c|c|c|c|c|}
\hline Genus & Species & Virus name & Abbrev & Tissue source & Age affected & References \\
\hline & $\begin{array}{l}\text { Rodent chaphamaparvo- } \\
\text { virus } 1\end{array}$ & $\begin{array}{l}\text { Mouse kidney parvovirus } \\
\text { Murine chapparvovirus }\end{array}$ & MKPV MuCPV & K & Unknown & $\begin{array}{l}{[7]} \\
{[223]}\end{array}$ \\
\hline & $\begin{array}{l}\text { Rodent chaphamaparvo- } \\
\text { virus } 2\end{array}$ & Rat parvovirus 2 & RPV2 & Feces & Unknown & {$[334]$} \\
\hline & $\begin{array}{l}\text { Ungulate chaphamapar- } \\
\text { vovirus } 1\end{array}$ & Porcine parvovirus 7 & PPV7 & Feces & Unknown & {$[315]$} \\
\hline & NA & Tilapia parvovirus & TiPV & Feces & Adult & {$[6]$} \\
\hline & NA & $\begin{array}{l}\text { Duck associated chap- } \\
\text { parvovirus }\end{array}$ & $\mathrm{DAC}$ & $\begin{array}{l}\text { Oropharyn-geal and cloa- } \\
\text { cal swabs }\end{array}$ & Unknown & {$[330]$} \\
\hline
\end{tabular}

Abbreviations are those defined by the ICTV or based on the literature. References are of peer-reviewed literature describing either the first detection or first full genome sequence of a virus as recognized by the ICTV

NA Not assigned by ICTV up to 2020 [20], S Spleen, Lu Lung, K Kidney, MLN Mesenteric lymph node, Li Liver, SI Small intestine, I Intestine, LN Lymph node, CSF Cerebrospinal fluid, NP Nasopharyngeal

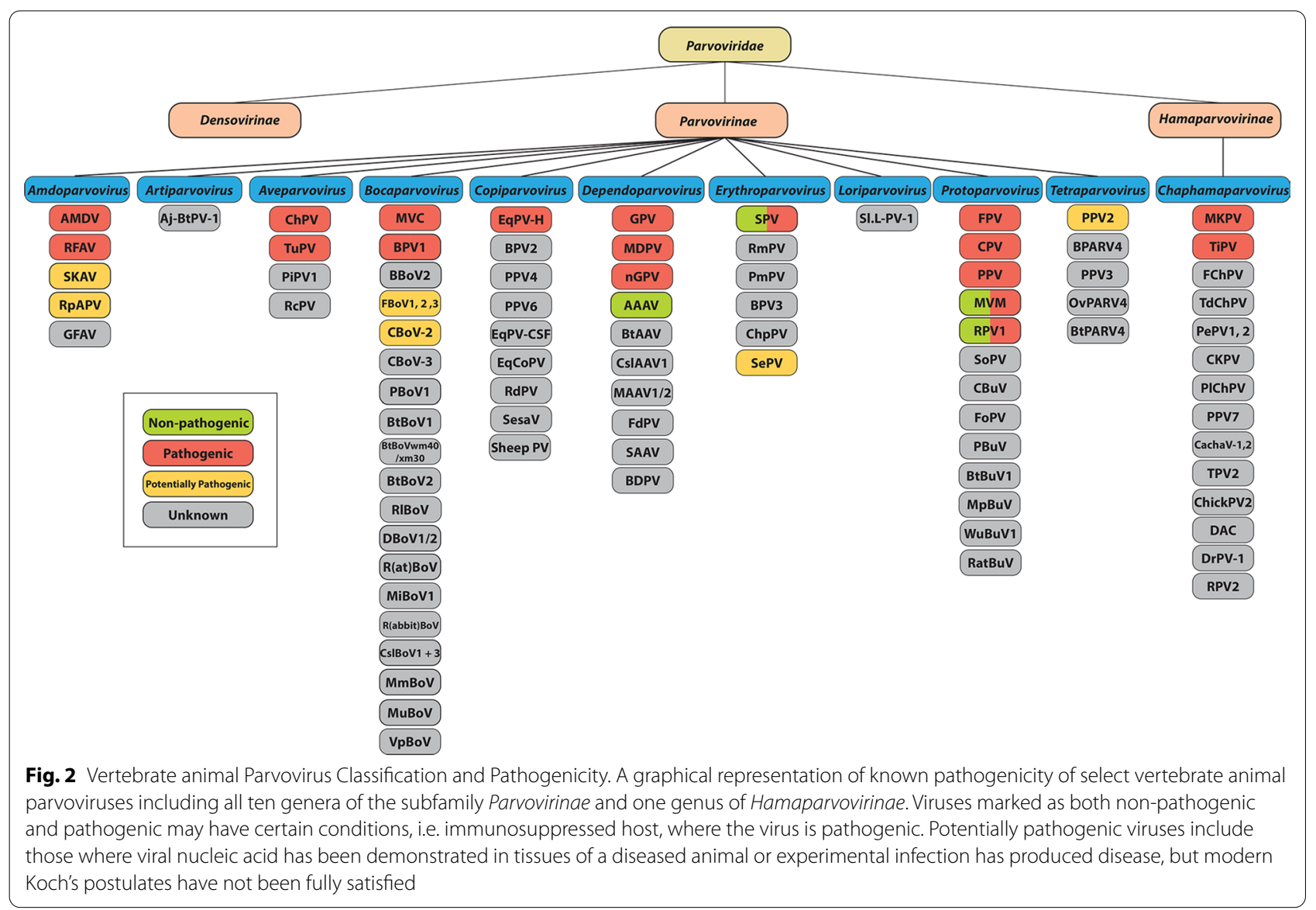

nonstructural proteins (NS1-NS3) via alternative mRNA splicing. The NS1 is a large multidomain protein that plays a central role in DNA replication, as it has strandand site- specific endonuclease (nicking) activity, an SF3 helicase domain with 3 ' to 5 ' processivity, rolling circle replication initiator protein motifs, and DNA binding domains. NS1 can also play an essential role in the regulation of the DNA damage response (DDR) and apoptosis pathways, which can be critical for successful completion of the viral infection cycle and contribute to pathology [24].

The VP gene (sometimes named Cap for the AAVs) encodes the capsid proteins that form the capsid. Parvovirus capsids can be composed of up to 4 VPs (VP1-4) 


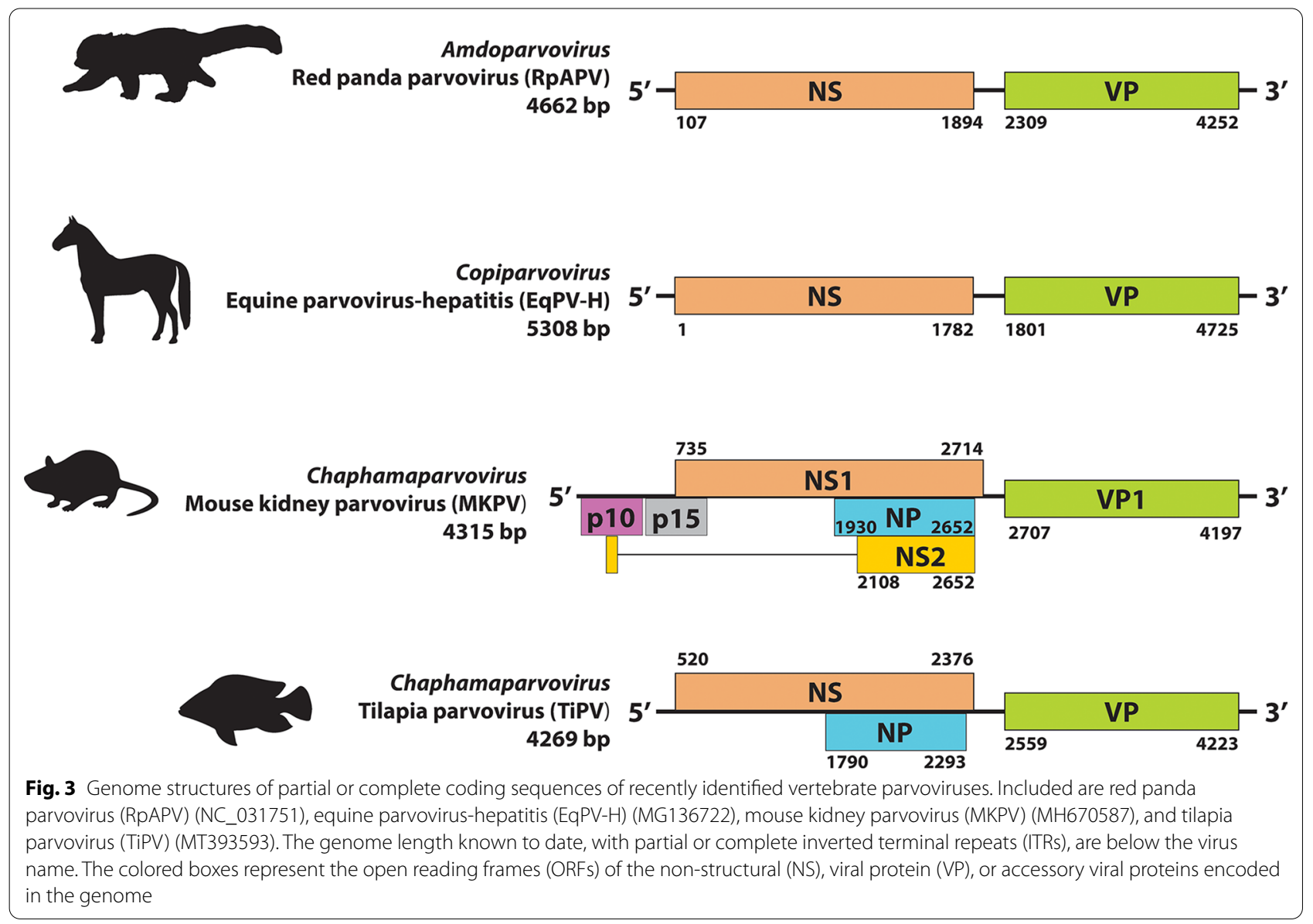

that are generated from a single ORF by alternative splicing and all share a common large C-terminal region. Generally, VP1 is the largest protein and comprises 10\% (out of 60 total VP units) of the capsid [14, 15]. In many parvoviruses, the extended N-terminus of the VP1 protein also includes the phospholipase A2 ( $\left.\mathrm{PLA}_{2}\right)$ enzymatic domain that is essential for cell entry due to the need to release from the endosomal or lysosomal pathway $[14,15]$. Additional features of the VP1 N-terminal sequence include a calcium-binding domain (part of the $\mathrm{PLA}_{2}$ structure) and a nuclear localization signal $[14,15]$. The smallest VP is expressed at a higher rate and comprises the majority of the viral capsid [17]. Capsids range from 22 to $28 \mathrm{~nm}$ in diameter with $\mathrm{T}=1$ icosahedral symmetry, and most have a cylindrical pore at the fivefold axis that is used for genome packaging and exit, as well as for exposure of the $\mathrm{N}$-terminal sequences of the VP2 protein in DNA-containing capsids [14, 15]. These parvovirus capsids can survive for long periods outside the cell, resulting in persistence in the environment, carriage on fomites, and wide dissemination $[25,26]$.

In addition to the core NS and VP proteins, most parvoviruses express small numbers of ancillary proteins with various functions. For example, a smaller nonstructural protein called NP1 is found in the viruses of the genus Bocaparvovirus [27]. Other ancillary proteins include NS2 and SAT for minute virus of mice (MVM), $7.5 \mathrm{kDa}$ and $11 \mathrm{kDa}$ for B19 virus, AAP for adeno-associated virus 2, NS2 for Aleutian mink disease virus, and NP in chaphamaparvoviruses [27-32].

\section{Replication}

Replication of the single-stranded (ss) DNA genome of Parvoviridae involves a complex multi-stage process that requires specific host cell conditions that vary by virus and can include cell cycle status, activation of the DNA damage response pathways, or the presence of a helper virus (Fig. 4]. As mentioned above, parvovirus genomes encode few proteins and lack a viral DNA polymerase, and therefore, require host cell enzymes [14, 15]. Unlike some other DNA viruses, like adenoviruses and polyomaviruses, parvoviruses lack the ability to initiate cell division despite their reliance on mitotically active cells with active DNA polymerase and other replication factors to complete their replication [14, 15]. While some dependoparvoviruses are able to complete their infection 


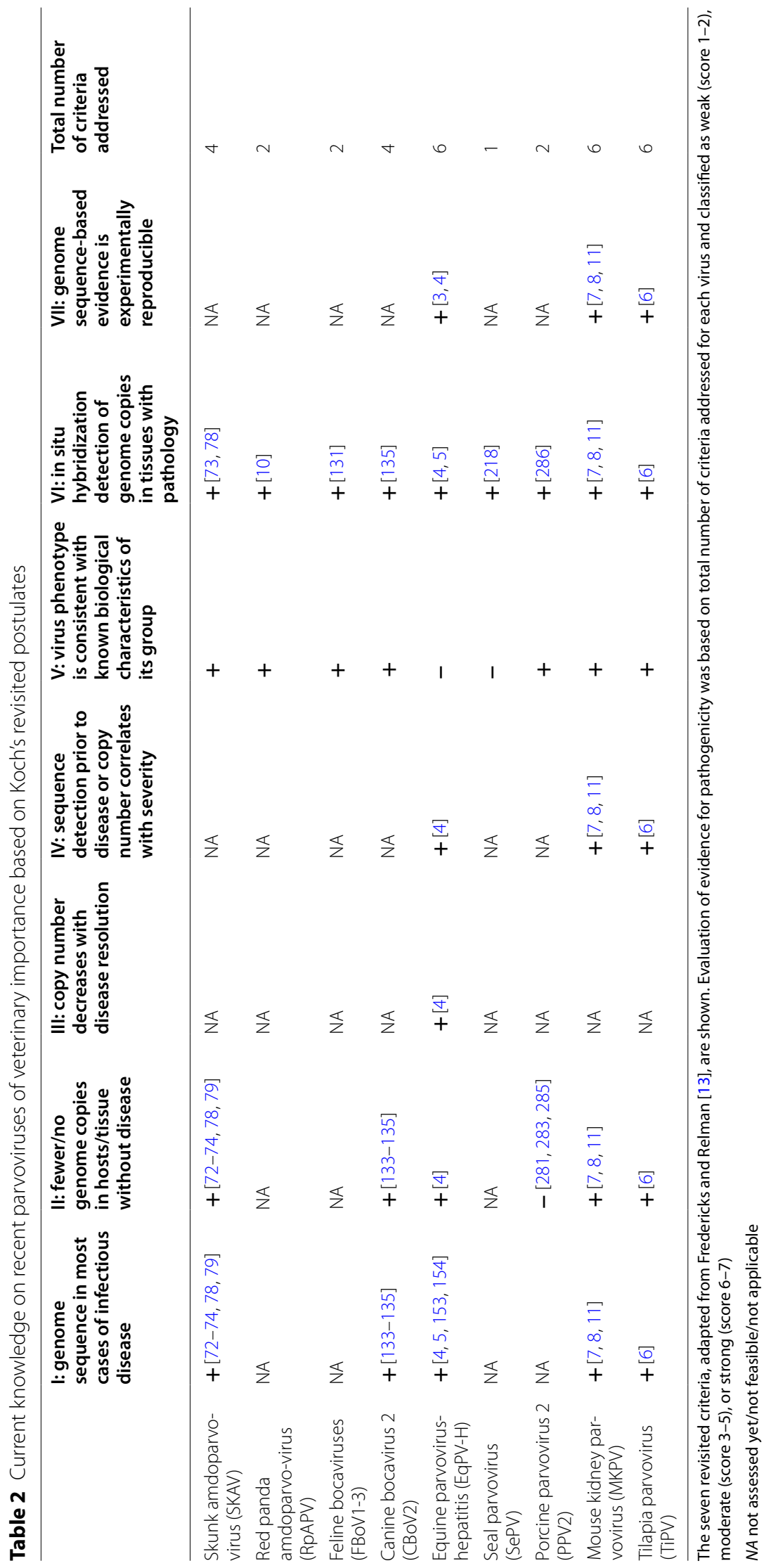




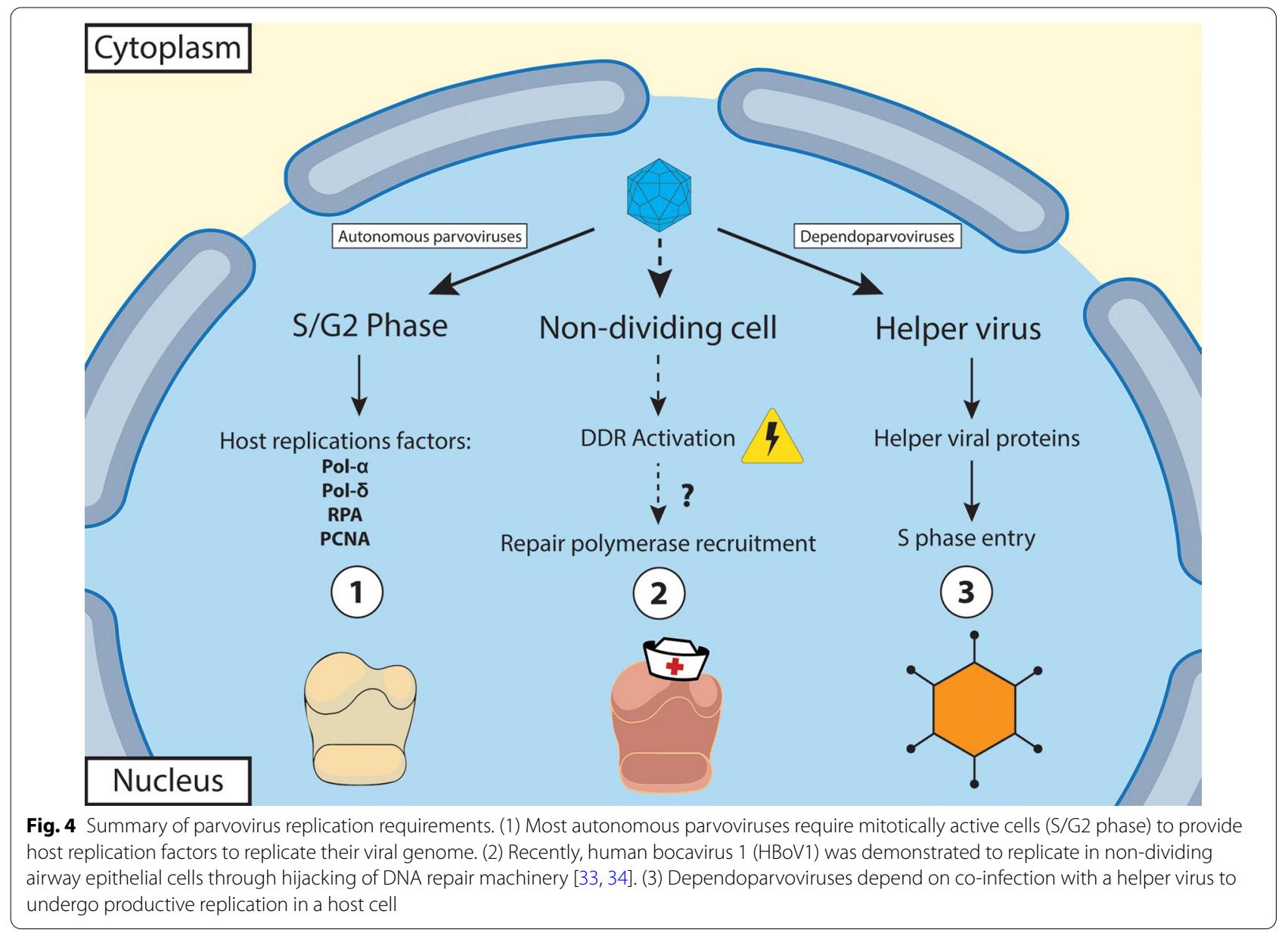

cycle in both dividing and non-dividing cells due to assistance from their helper viruses, the dependence on the cell cycle status of the infected cell was considered a defining feature of autonomous parvoviruses and plays a significant role in tissue tropism and disease manifestation $[14,15]$. However, recent studies have demonstrated that human bocavirus-1 (HBov-1) is able to hijack host cell DNA damage response pathways and the DNA repair machinery to replicate its genome in non-dividing airway epithelial cells (Fig. 4) [33, 34]. Indeed, in all autonomous parvoviruses studied to date, activation of one or more of the DDR PI3-kinase-like kinases is essential for productive infection $[14,35,36]$. Activation of the DDR during infection is also seen in other DNA viruses including papillomaviruses and herpesviruses [37-40].

\section{Pathogenesis}

Many vertebrate parvoviruses have been identified in non-primate species, and the pathogenesis of human parvoviruses such as B19 virus, HBov-1, and human parvovirus 4 have been reviewed elsewhere $[41,42]$.
While most pathogenic animal parvoviruses affect the young, some, like EqPV-H, appear to cause disease in adults only whereas others, including Aleutian mink disease virus (AMDV), can cause disease in both young and adult animals with different disease manifestations [43, 44]. In general, disease outcome is controlled by various factors. One factor is the need for cellular $\mathrm{S}$ phase to access DNA replication machinery and co-factors, so that tissues with a high cellular division rates will be disproportionately affected. Other factors are more complex and include specific regulation of viral transcription and splicing [45-47]. For example, rapidly dividing enterocytes in the epithelial crypts of the intestine of a dog or cat are infected and killed by canine (CPV-2) and feline (FPV) parvoviruses, resulting in enteric disease [48-52], and infection of rapidly dividing cells of the immune system and bone marrow results in panleukopenia in FPV-infected cats. In some instances, the virus is only clinically relevant in immunosuppressed animals, as seen with simian parvovirus infection in macaques $[53,54]$. AMDV infection in adult mink, while variable, is characterized by chronic viral replication leading to 
inflammation and type III hypersensitivity reactions, rather than direct, virally-induced acute necrosis or apoptosis [44, 55-59].

We will now describe some of the parvoviruses of greatest significance in animals, with a special emphasis on emerging and/or novel parvoviruses associated with clinical disease where research progress has been made in the past four years.

\section{Genus Amdoparvovirus}

Until 2011, the only known member of the genus Amdoparvovirus (formerly Amdovirus) was Carnivore amdoparvovirus 1, also known as Aleutian mink disease virus (AMDV). Additional species have been identified, including Carnivore amdoparvoviruses 2-5 (grey fox, racoon dog and fox, skunk, and red panda amdoparvoviruses, respectively), and many others are likely to exist (Fig. 2, Table 1). Recently, a novel amdoparvovirus with $82.7 \%$ aa identity to AMDV was identified in rodent pharyngeal and anal swabs[60]. These viruses have a heterotelomeric genome of $\sim 4.8 \mathrm{~kb}$ with two major ORFs, encoding the nonstructural proteins NS1, NS2, NS3, and the two structural proteins VP1 and VP2 (Fig. 3). The VP1 N termini of amdoparvoviruses are unusually short and lack a $\mathrm{PLA}_{2}$ enzymatic domain [61-65].

\section{Aleutian mink disease virus (AMDV)}

Aleutian mink disease (AD), also known as mink plasmacytosis, arose through a combination of economic opportunity and genetic selection. AD was first observed in the US during the 1940s and was initially recognized as a wasting condition in a light-colored mutant of mink called Aleutian mink, based on resemblance with the Aleutian fox coat color that is associated with a lysosomal storage disease (related to Chediak-Higashi syndrome in humans), which likely impairs clearance of immune complexes [66]. Following the commercial success of this new pelt color, Aleutian minks were shipped world-wide. While the wasting condition recognized by the mink farmers was initially attributed to a genetic disease associated with the coat color, subsequent research identified the culprit as AMDV $[66,67]$.

AMDV causes disease primarily in captive American minks, particularly of the Aleutian coat color, but the host range under natural and experimental conditions includes wild and captive mustelids (weasels, badgers, otters, ferrets), cats, dogs, fox, lynx, racoons, bobcats, skunks, and mice [43, 68-74]. Interestingly, $\mathrm{AD}$ has been recognized as an occupational disease of mink farmers [75]. Disease in adult minks is manifested as a persistent infection that leads to immune complex disease characterized by progressive wasting and anorexia, lymphadenomegaly and splenomegaly, proliferative glomerulonephritis, necrotizing arteritis, hypergammaglobulinemia, and plasmacytosis [44, 76]. Anti-capsid antibodies enhance viral entry into macrophages via binding to Fc receptors, resulting in antibody-dependent enhancement of infection $[55,56]$. The continuing antibody and viral production leads to the formation of perivascular and glomerular virus-antibody complexes that are deposited in various tissues, leading to type III hypersensitivity with arteritis and glomerulonephritis [55-59]. In young minks, the virus causes an acute disease due to the direct infection and clearance of type II pneumocytes, resulting in fulminant interstitial pneumonia that is often fatal within 3 weeks post-infection [43, 77, 78].

Control was mainly focused on antibody testing and culling, but despite improvements in surveillance testing and biosecurity in recent years, AMDV infections continue globally, likely because of persistence of the virus in the environment [79]. Molecular epidemiology has revealed viral spread within and between farms in multiple countries, and identified regions of increased AMDV prevalence and risky farming practices [80-86]. Recent epidemiologic studies are examining cross-species transmission and viral lineages to identify maintenance hosts that enable viral persistence and viral sources for susceptible species across the globe [87].

\section{Other amdoparvoviruses}

Raccoon dog and fox amdoparvovirus (RFAV) was first recognized following a disease outbreak on six farms raising captive Asiatic racoon dogs and artic foxes in China [88]. Clinical signs in racoon dogs included emaciation, growth retardation, chronic diarrhea, increased thirst, and unkempt fur. Splenomegaly, lymphadenomegaly, and renal cortex congestion were noted at necropsy. Similarly, emaciation and growth retardation were reported in 3-month old artic fox cubs [88].

Skunk amdoparvovirus (SKAV) is related to AMDV, with potential for serological cross-reactivity [89], and early accounts of amdoparvovirus infection in skunks were likely caused by SKAV. Naturally-occurring ADlike disease was first described in two companion striped skunks with biochemical and histologic changes considered typical of AD in mink and ferrets [90]. Several studies have identified the virus or viral DNA in apparently healthy free-ranging striped skunks in both Canada and the US [69, 89, 91-96]. In recent studies, 43/50 (86\%) and 140/216 (64.8\%) of free-ranging skunks in British Columbia and California, respectively, tested positive for amdoparvovirus DNA[91, 96]. This high prevalence suggests endemic infection in free-ranging skunks. Many PCR-positive skunks had histologic lesions in the kidneys, heart, brain, liver, or lungs similar to the early 
descriptions of amdoparvovirus in skunks, but only few cases had signs of glomerulonephritis or arteritis [95, 96]. Other clinical signs in both adult and juvenile skunks included neurological signs, emaciation, and lethargy [96]. Although PCR and ISH testing revealed viral NA in liver and spleen of SKAV-infected skunks, providing moderate evidence of pathogenicity [90], elucidating the full tissue distribution of this virus will help confirm its pathogenic role in the variety of observed clinical signs (Table 2).

Red panda amdoparvovirus (RpAPV) was detected by PCR in tissues and feces of six captive red pandas housed at the Sacramento Zoo from 2003 to 2016 [10, 20]. Three animals were healthy when tested, while the other three PCR-positive animals, all geriatric, died and were submitted for necropsy [10]. Histologically, one case presented with inflammatory infiltrates in the mesentery, intestines, pancreas, and myocardium, whereas another case had lytic cells with intranuclear inclusions in oral cavity tissue. ISH and electron microscopy (EM) were performed, and ISH positive cells where present in the germinal centers of lymphoid tissues of all four cases examined, and within scattered individual cells in the lamina propria and mucosa of the intestines of three cases [10]. In one case, hybridization was also consistently detected in areas of inflammation. The morphology of these ISHpositive cells was suggestive of macrophages. EM of lingual epithelial tissue demonstrated capsids of $\sim 22 \mathrm{~nm}$ in diameter, consistent with other parvoviruses [14, 15]. These findings provide weak evidence of pathogenicity, and additional studies examining the prevalence, diversity, and pathogenicity, of RpAPV in captive and freeranging red pandas are needed to clarify the significance of this virus for global conservation efforts (Table 2). Red pandas are listed as endangered by the International Union for Conservation of Nature and considered threatened with extinction by the Convention on International Trade in Endangered Species, so experimental studies of RpAPV infection and disease are not possible [97].

Gray fox amdoparvovirus (GFAV) was first detected in a gray fox in California in 2009 [98]. This animal presented with severe gait abnormalities, lymphadenopathy, and acute muscle inflammation, and was subsequently euthanized. GFAV was also detected in the lung and heart tissues of an additional fox with similar signs. However, nine other foxes with similar clinical signs tested negative for GFAV in this study, and thus, it is likely that the DNA was an incidental finding in the two foxes that tested PCR positive.

Recently, two new amdoparvoviruses were detected in various tissues of Canadian carnivores [74]. Labrador amdoparvovirus 1 (LaAV-1) was identified in foxes and martens and Labrador amdoparvovirus 2 (LaAV-2) was identified in one fox. LaAV-1 was most similar to viruses of mink and skunks, with capsid proteins in some regions almost indistinguishable from those of AMDV [74]. In contrast, LaAV-2 was more closely related to other viruses infecting canids.

\section{Genus Artiparvovirus}

This new established genus currently includes only one member, Artibeus jamaicensis parvovirus (Aj-BtPV-1, Chiropteran artiparvovirus 1) (Fig. 2) [99]. This virus was detected in whole EDTA blood samples of leaf-nosed fruit bats in Panama and is currently not associated with clinical disease.

\section{Genus Aveparvovirus}

The genus Aveparvovirus is composed of three official members, all of which have been detected in avian species (Fig. 2, Table 1). The species Galliform aveparvovirus 1 includes two viral strains, chicken parvovirus (ChPV) and turkey parvovirus (TuPV), which are widespread and highly infectious to young poultry, although their disease association remains uncertain. The other species are Columbid aveparvovirus 1 (pigeon parvovirus 1) and Gruiform aveparvovirus 1 (red-crowned crane parvovirus), in addition to a recently identified aveparvovirus in a grey pileated finch. Aveparvoviruses lack a PLA ${ }_{2}$ motif in their VP1 proteins. Since avian parvoviruses have been recently reviewed elsewhere [100], we will only describe their main features here, emphasizing recent findings.

\section{Chicken (ChPV) and Turkey (TuPV) parvoviruses}

These two viruses are widespread amongst commercial poultry, including the US, Hungary, Poland, and Croatia [101-105], and ChPV has also been reported in South Korea, China, India, Brazil, Ecuador, Canada, and the UK [106-112]. While ChPV and TuPV have been associated with malabsorption syndrome in chickens and the occurrence of enteritis in turkeys, respectively, the contribution of these viruses to disease remains unclear as they are also detected in healthy birds [103, 105, 113-119]. Runting and stunting syndrome (RSS) in broilers is a multifactorial condition first reported in the 1940s, characterized by impaired growth and poor feed conversion because of enteritis, and is associated with several other viruses [e.g. astrovirus, coronavirus, rotavirus, reovirus), bacteria, and coccidia [111, 113, 120-124].

Experimental infection of specific-pathogen-free 1-day old chicks with ChPV resulted in rapid development of enteritis and diarrhea that persisted until 42 days of age, whereas mock-inoculated birds did not develop any clinical signs or macroscopic lesions [123]. Infected birds in all age groups presented with intestinal volvulus, a feature reported in RSS cases, and developed enteritis 
characterized by dilated crypts and acute pancreatitis [123]. Although many questions remain about the relationship between ChPV and RSS, a causal relationship between ChPV and enteric disease in young chickens seems likely.

\section{Other aveparvoviruses}

Analysis of aveparvovirus DNA in the droppings of wild pigeons in Hong Kong and Hungary showed a close, but distinct, relationship with ChPV and TuPV and was named pigeon parvovirus 1 (PiPV1) [125]. A study in Brazil identified another parvovirus sequence in the droppings of a gray pileated finch, tentatively named Passeriform aveparvovirus [126]. Red-crowned crane parvovirus (RcPV) was detected in a fecal virome of wild and captive red-crowned cranes in China [20, 127]. These three aveparvovirues were detected by sequencing and PCR, and any potential disease association is unknown.

\section{Genus Bocaparvovirus}

The genus Bocaparvovirus (formerly Bocavirus) is the largest in the Parvoviridae family and currently includes over 25 species from many animal hosts, such as carnivores, bats, and ungulates (Fig. 2, Table 1). Human bocavirus 1 (Primate bocaparvovirus $1, \mathrm{HBoV}-1$ ) was first detected in 2005 in the nasopharyngeal aspirates of children with respiratory tract infections, and is associated with respiratory tract infections and acute otitis media in young children [41, 128]. Recent discoveries in this genus include two new Ungulate bocaparvovirus species (Ungulate bocaparvovirus 7 and 8) and two new Rodent bocaparvovirus species (Rodent bocaparvovirus 1 and 2) [20]. Bocaviruses have heterotelomeric genomes $\sim 5$ to $5.5 \mathrm{~kb}$ and package predominantly negative-sense DNA $[27,129,130]$. Bocaparvoviruses encode for an NP1 protein that plays a role in RNA processing, as mentioned previously [131, 132]. Most bocaparvoviruses were discovered after 2010 by metagenomic analysis of fecal DNA (Table 1). While many of these new viruses are widespread, none have been unequivocally demonstrated to be pathogenic in animals (Fig. 2).

\section{Minute virus of canines (MVC)}

MVC (Carnivore bocaparvovirus 1), also known as Canine minute virus (CnMV) or canine parvovirus type-1 (CPV-1), was first isolated from feces of healthy dogs in 1967 and has since been associated with a range of pathologies in dogs of different ages [133]. Initial in vivo experimental inoculations suggested that MVC was apathogenic, but a virus with fewer in vitro passages caused severe respiratory disease in 5-day old puppies [134]. Natural outbreaks of MCV-associated neonatal mortality have also been reported [134-136]. Gross lesions in these naturally infected puppies included diarrhea and pale streaks in the heart. Histologic findings of large eosinophilic intranuclear inclusions in jejunal enterocytes, intestinal crypt necrosis, lymphoid depletion, pneumonia, and myocardial necrosis, were also described [135]. Transplacental transmission in pregnant dogs has been described and can result in embryonic resorption, abortion, stillbirth, birth deformities, or neonatal mortality [137-139].

\section{Bovine bocaparvoviruses (BPV)}

The hemadsorbing enteric virus BPV1 (Ungulate bocaparvovirus 1) has been recognized for decades and was first discovered in 1961 in the gastrointestinal tract of calves with diarrhea [140], but appears to be widespread in both healthy and diarrheic calves. In calves, BPV1 can cause watery to mucoid diarrhea following infection of enterocytes throughout the small intestine. It has also been associated with spontaneous abortions and stillbirths in adult cattle [141]. Like some other pathogenic parvoviruses, BPV infection will start with initial replication in the tonsils and gut and spread to lymphoid organs where it will result in transient lymphopenia. Viral antigen has been detected in multiple tissues including the epithelium of intestinal crypts, thymus, lymph nodes, adrenal glands, and heart [142]. BPV1 has been analyzed with high resolution $\mathrm{X}$-ray and cryo-EM, providing a model for other members of this genus [15].

More recently, the DNA of BPV2 (Ungulate bocaparvovirus 6 ), which shares $64 \%$ NS1 aa identity with BPV1, was detected in nasal swabs of cattle in the US and Mexico in 2015 [143]. However, the prevalence was equal in cattle that were either healthy or suffered from acute bovine respiratory disease, so disease association is currently unknown.

\section{Feline bocaviruses (FBoV)}

DNA of FBoV (currently FBoV1 to FBoV3) was recently discovered in domestic cats and these viruses have been assigned to Carnivore bocaparvovirus 3-5, respectively. FBoV1 was first detected in feces, blood, kidney, and nasal swabs of clinically normal domestic cats in Hong Kong in 2012 [144]. FBoV2 and FBoV3 were subsequently discovered in a high throughput metagenomic study of feline fecal viromes $[145,146]$. FBoV have been detected in the feces of symptomatic and asymptomatic cats in Portugal, Japan, China, Belgium, Thailand, and the US [145-150]. Testing for FBoV in feces of stray cats with and without signs of diarrhea in China yielded one positive case, a three-month-old male cat with severe enteritis [129]. FBoV1 was detected in cats from different households with hemorrhagic enteritis during an outbreak of feline panleukopenia virus (FPV) in Thailand [150]. Using 
ISH, parvoviral NA was detected in intestinal cells and vascular endothelium of the intestinal mucosa and serosa, with co-infecting FPV detected via IHC. The coding sequences revealed high inter-strain genetic diversity and possible NS1 recombination in one of three FBoV1 strains [150]. One year later, FBoV1 to -3 were detected in the feces of cats during an outbreaking of vomiting and diarrhea in a system of shelters in British Columbia, Canada [151]. Although the pathogenicity of $\mathrm{FBoV}$ in cats remains unclear based on weak evidence, the presence of parvoviral NA in the intestine of cats with hemorrhagic enteritis [150] suggests a pathogenic association of this virus, alone or in combination with other viruses such as FPV (Table 2). The common finding of the virus or viral DNA in healthy cats suggests mostly subclinical infections, with disease under some circumstances.

\section{Other bocaparvoviruses}

The DNA of two novel bocaviruses has been reported in dogs in recent years, although without any definitive association with clinical disease. Canine bocavirus 2 (CBoV2) of the species Carnivore bocaparvovirus 2 was discovered during a metagenomic study of dogs with respiratory disease and has also been detected in fecal samples from stray dogs in a surveillance program and in a litter of puppies with fatal enteritis [144, 152, 153]. Although $\mathrm{CBoV} 2$ has been detected more frequently in dogs with respiratory disease compared to healthy dogs, a clear connection with pathology has yet to be established. A novel strain of CBoV2 was identified in a litter of puppies that died of acute dyspnea and hemoptysis using next generation sequencing (NSG) and the tissue distribution was assessed using qPCR and ISH [154]. Hybridization was detected in intestinal epithelial cells and EM confirmed the presence of particles within intranuclear inclusions of small intestinal enterocytes. Nonetheless, it remains unclear what role this infection played in the death of the puppies and the evidence of pathogenicity is weak (Table 2). Canine bocavirus 3 (CBoV3) was discovered in the liver of a dog co-infected with a novel circovirus [155].

Porcine bocavirus 1 (PBoV1) was first discovered in the lymph nodes of pigs affected by post-weaning multisystemic wasting syndrome (PMWS) in Sweden in 2009 [156], and has been detected worldwide in both healthy and clinically ill pigs. Its epidemiology, evolution analysis, detection methods, and pathogenesis have been recently reviewed elsewhere [157]. While the pathogenicity of $\mathrm{PBoV}$ is unclear, it has been detected in association with a wide array of clinical signs, and co-detected with other viruses such as porcine circovirus type 2, porcine reproductive and respiratory syndrome virus, and torque teno sus virus [158-160].
In the last decade, several new species of bat bocaviruses have been discovered through metagenomic analyses of various bat species. Myotis myotis bocavirus 1 (BtBoV1, Chiopteran bocaparvovirus 1) was detected in pharyngeal and anal swabs from 11 insectivorous bat species in China in 2012 [161]. The bat bocaviruses WM40 and XM30 (Chiopteran bocaparvovirus 2 and 3, respectively), were detected in organs of insectivorous bats in Myanmar in 2013 [162]. Miniopterus schreibersii bat bocavirus (BTBoV2) of the genus Chiopteran bocaparvovirus 4 was discovered in spleen, respiratory, and alimentary, samples of six bat species in China in 2017 [163]. A higher prevalence of BTBoV2 in the bat species Rhinolophus sinicus led the authors to suggest that this bat could be the primary viral reservoir. BTBoV2 was also more frequently detected in female bats and prevalence was higher during lactating seasons. The same authors performed a similar study one year later and identified Rousettus leschenaultii bocaparvovirus 1 (RIBoV, Chiopteran bocaparvovirus 5), as well as a few other novel bat bocaviral sequences [164].

Other Bocaparvovirus DNA has been found in dromedary camels, rats, mink, rabbits, sealions, as well as other animal species (Table 1). The dromedary camel bocaparvoviruses (DBoV)1 and -2 (Ungulate bocaparvovirus 7 and 8 , respectively), were discovered through a metagenomic analysis of dromedary camels in Dubai [165]. Interestingly, while $N S 1 / N P 1 / V P 1-2$ genes were observed in both viruses, a phospholipase $\mathrm{A}_{2}$ motif was not detected in the VP1 sequences of 18 isolates and no start codons were found for the VP1 ORF [165]. Rat bocavirus (RBov, Rodent bocaparvovirus 1) DNA has been detected in the alimentary and respiratory tracts, spleen, and kidneys, of Norwegian brown rats in China [164, 166]. Mink bocavirus 1 (MiBoV1, Carnivore bocaparvovirus 6) was detected in feces of healthy and sick mink from a breeding center [167]. Rabbit bocaparvovirus (RBoV, Lagomorph bocaparvovirus 1) DNA was discovered in the feces of rabbits with enteric disease, but association with disease is not clear [168]. California sea lion bocavirus (CslBoV)1 and -3 (Pinniped bocaparvovirus 1 and 2, respectively) DNA has been detected among fecal samples collected from free-ranging California sea lions in California [169].

\section{Genus Copiparvovirus}

Viruses in this genus have only been identified in mammals thus far, the clinical significance of most remains in question, and none have been cultured in vitro (Fig. 2, Table 1). Copiparvoviruses were first identified in domestic cows and pigs using DNA sequencing, then equine parvovirus-hepatitis (EqPV-H) was identified in horses. The genomic organization includes $N S$ and $V P$ genes, 
and genome lengths vary between 5.3 and $5.9 \mathrm{~kb}$ [170] (Fig. 3). Detailed information on protein expression and/ or telomere structure are not yet available.

\section{Equine parvovirus-hepatitis (EqPV-H)}

Fulminant acute hepatic necrosis in horses was first described in 1918 by Sir Arnold Theiler and became known as Theiler's disease [171]. Thousands of horses were vaccinated for African Horse Sickness by administration of pooled convalescent horse serum along with live virus. Four to 24 weeks after treatment, $2-18 \%$ of the horses succumbed to hepatic necrosis. Some unvaccinated horses living with vaccinated horses also developed hepatic necrosis, while horses on properties without vaccination had less or no hepatitis. These findings suggested the condition to be both transmissible and contagious, although an infectious agent was not identified.

One hundred years later, in 2018, EqPV-H was identified by NGS of a liver sample from a horse that died of Theiler's disease [3], and was confirmed to be the primary pathogen in Theiler's disease cases through prospective case series [172, 173]. Examination of the tissue distribution of viral DNA by qPCR and ISH, demonstrated that the virus is hepatocytotropic [4]. It appears that EqPV-H mostly causes subclinical or mild hepatitis, with the fulminant hepatic necrosis (Theiler's disease) being a rare outcome [4]. Pathologic findings in mild cases include individual hepatocyte necrosis and lymphocytic infiltrates [4], while severe cases have centrilobular-to-massive hepatocyte necrosis with variable inflammatory infiltrate, vacuolar changes in spared portal areas, and biliary reaction $[172,173]$. A prolonged period of high viremia before the onset of hepatitis suggests that the virus might not be directly cytolytic, but it remains to be determined whether pathology is a direct effect of the virus or is immune-mediated.

EqPV-H is present worldwide and both viral infection and presence of viral DNA are common in horses, with a serum PCR prevalence of $8-37 \%$ and a seroprevalence of $15-35 \%$ [3, 5, 174-179]. qPCR analysis of historical samples of horses with Theiler's disease from 1981 demonstrates that this virus has been circulating at least 40 years (Dr. Thomas J. Divers, personal communication). Transmission via iatrogenic administration of equine biologic products is well documented, and other modes of transmission are being explored [4]. A seasonal pattern of non-iatrogenic Theiler's disease cases in the summer and fall suggests an insect vector [172, 173], although a horse fly transmission study did not result in viral spread [4]. Oral, nasal, and fecal shedding of viral DNA has been demonstrated and successful oral transmission of one single horse reported, however, the primary route of transmission is not yet known. Vertical transmission has not been observed [4]. While these findings provide strong evidence of pathogenicity, much remains to be determined, including what governs tissue tropism and influences disease severity (Table 2).

\section{Other copiparvoviruses}

The genus Copiparvovirus includes bovine parvovirus 2 (BPV2) and porcine parvovirus 4 (PPV4) (Ungulate copiparvovirus 1 and 2, respectively) [170, 180]. BPV2 DNA was found in bovine sera, including pooled serum samples of calves in the US $[180,181]$. BPV2 DNA was also detected in metagenomic analysis of bovine pneumonic lung samples in Canada, although its presence was not significantly associated with pneumonia [182]. Other bovine copiparvoviruses have been identified in bovine and fetal bovine serum, including the bovine copiparvovirus species 3 isolate JB9 [183] and Bosavirus (BosaV, Ungulate copiparvovirus 5) [181], respectively. These findings suggest bovine parvovirus DNA, and perhaps virus, might be present in many products produced using bovine serum.

PPV4 DNA was initially detected in lung lavages of pigs infected with porcine circovirus type 2 in the US and has subsequently been detected in a variety of tissues of both healthy and sick pigs in the US, China, Vietnam, Thailand, Japan, Poland, Hungary, South Africa, and Cameroon [184-191]. PPV4 has also been detected in bush pigs in Uganda and wild boar in Romania and South Korea [187, 192, 193]. The pathogenicity of PPV4 remains unclear. Porcine parvovirus 6 (PPV6, Ungulate copiparvovirus 4) was first identified in aborted pig fetuses in China, with a higher prevalence in aborted pig fetuses and piglets compared to finishing pigs and sows [194]. Later, PPV6 was detected in serum samples from pigs in nine US states and one state in Mexico [195]. However, the clinical significance of the virus remains undetermined.

In horses, two other copiparvoviruses have been identified to date. The first was discovered in a cerebrospinal fluid (CSF) sample from a horse with neurological signs and leukocytic pleocytosis in 2015 [196]. This viral DNA, named horse parvovirus-CSF, was detected in thoroughbreds in China in 2018 and in metagenomics analysis of samples from horses with unexplained neurological or respiratory signs $[178,197]$. In the latter study, another copiparvovirus was identified, tentatively named equine copiparvovirus (EqCoPV) and its NS1 protein shares $43.4 \%$ and $31.3 \%$ aa identity to horse parvovirus-CSF and EqPV-H NS1, respectively [178].

Roe deer copiparvovirus (RdPV, Ungulate copiparvovirus 3) DNA was identified through metagenomic sequencing of Ixodes ricinus ticks and European roe deer in Belgium [198]. The RdPV genome encodes for two putative ORFs and its NS gene has 55\% nucleotide 
identity to BPV2, its closest relative. Importantly, the presence of the virus in both deer and ticks suggests a role for ticks in transmission of these parvoviruses, although that has not been confirmed.

Sesavirus (SesaV, Pinniped copiparvovirus 1) is a nonungulate copiparvovirus and its DNA was detected in the feces of a California sea lion pup with malnutrition and pneumonia [199]. The identity of the putative SesaV NS and VP proteins to the closest members of the genus are only $25 \%$ and $28 \%$ aa, respectively. The putative sheep copiparvovirus 1 (Sheep PV) was detected in metagenomic sequences of samples from an abortion outbreak in sheep, and shares $<30 \%$ identity with the NS aa sequence of other copiparvoviruses and $<20 \%$ identity with members of other genera in the Parvovirinae family [200].

\section{Genus Dependoparvovirus}

Viruses in this genus, formerly known as Dependovirus, are phylogenetically most similar to the genera Copiparvovirus, Erythroparvovirus, Artiparvovirus, Loriparvovirus, and Tetraparvovirus. Most of its members are adeno-associated viruses (AAVs), which require helper viruses to complete their viral infection cycle (Fig. 2, Table 1) [100]. However, the goose parvovirus (GPV) and Muscovy duck parvovirus (MDPV) (Anseriform dependoparvovirus 1), are autonomous and replicate in tissues of growing goslings or ducklings [100]. Differences are seen in the organization of the genomes, with AAVs typically having identical, short terminal repeats of $\sim 145$ bp long with T-shaped hairpin telomeres of $\sim 125 \mathrm{bp}$, whereas GPV and MDPV have long identical telomeres of 442 to 456 bp, respectively [201].

The prototypical dependoparvovirus is the human adeno-associated virus 2 (AAV2), first discovered in the mid 1960s in contanimated laboratory adenovirus preparations [202, 203]. In the section "Animal viruses as therapeutics in humans", we will discuss the use of veterinary parvoviruses to replace human AAVs in efforts to improve gene therapy performance.

\section{Goose parvovirus (GPV) and Muscovy duck parvovirus (MDPV)}

GPV was first identified in China in 1962 and later in Hungary in 1967 [204, 205]. Disease is most severe in goslings and can result in a high mortality of $>90 \%$ in birds less than 4 weeks old. Gross lesions can include fibrinous pseudomembranes of the oral cavity, pericarditis, pulmonary edema, and catarrhal enteritis, and microscopic lesions include intranuclear inclusions and degenerative changes in myocardial cells [206]. MDPV is closely related to GPV with $87 \%$ nucleotide identity with GPV at the genome level and 91.2\% aa homology of the Rep (NS) protein [207] MDPV causes Muscovy duck parvoviral disease, first described in China in 1984 and characterized by respiratory signs, diarrhea, and dyskinesis, with a lower morbidity and mortality rate compared to GPV. This disease most commonly occurs in 3-week-old Muscovy ducklings and is commonly known as the "3-week" disease [201]. In more recent years, a recombinant MDPV (rMDPV) was identified in Chinese Muscovy ducks with a higher mortality and a catarrhal disease outcome similar to GPV [208, 209].

In 2015, a novel goose parvovirus (nGPV) was described in China in association with growth retardation, beak atrophy, enteritis, and paralysis [210-212]. Phylogenetic analysis revealed that these Chinese nGPV strains share $90.8-94.6 \%$ nucleotide identity with GPV and thus, are closely related [210]. While the disease, named short beak and dwarfism syndrome (SBDS), has a reportedly low mortality, the morbidity can be up to $20 \%$. More recently, SBDS has also been observed in Egypt and Poland [213, 214].

\section{Other dependoparvoviruses}

Many other AAVs have been discovered, and an avian AAV (AAAV) was first discovered in 1973 and subsequently cloned into recombinant vectors for use in avian gene therapy studies in postmitotic avian cells [215, 216]. These recombinant AAVs can be used to transduce avian neurons and retinal cells for manipulation of gene expression [217]. AAAV was used for the development of a vaccine against duck hepatitis A virus-1 [218].

Bat adeno-associated virus (BtAAV, Chiropteran dependoparvovirus 1) was identified in fecal swabs of 19 bat species in five Chinese provinces in 2007-2008 [219]. Intestinal samples from 5 species of bats in Southeast China showed that $18.6 \%$ were positive for AAVs, suggesting a wide distribution of these viruses [220]. Analysis of the BtAAV capsid structure using sequence analysis and cryo-EM revealed unique structural differences to human AAVs, including insertions and deletions in the capsid surface loops [221]. BtAAV capsids have been identified as possible vectors for gene therapy, as discussed later [221, 222].

Other dependoparvoviral DNA detected in fecal samples include (1) California sea lion adeno-associated virus 1 (CslAAV1, Pinniped dependoparvovirus 1), in feces of sea lions in California [169], (2) Murine adeno-associated virus (MAAV)1 and -2 (Rodent dependoparvovirus 1 and 2), respectively, in feces of house mice in New York City [223], and (3) Feline dependoparvovirus (FdPV, Carnivore dependoparvovirus 1), detected in two cats in an outbreak of vomiting and diarrhea in a shelter in British Columbia, Canada [151].

This genus also includes the only known reptilian parvoviruses, such as snake AAV (SAAV, Squamate 
dependoparvovirus 1), which has been isolated from a ball python, propagated in viper and iguana heart cells, and fully sequenced [224]. Partial genome sequences of a dependoparvovirus were detected in an Indonesian pit viper [225] and a chequerboard worm lizard [226]. A dependoparvovirus was detected in a bearded dragon (BDPV, Squamate dependoparvovirus 2) [227]. No diseases have been associated with any of these reptilian parvoviruses.

\section{Genus Erythroparvovirus}

The genus Erythroparvovirus (formerly Erythrovirus) includes viruses detected in a wide range of species including primates, seals, cattle, and rodents (Fig. 2, Table 1). Human parvovirus B19 (B19V) infection is common in humans, and can be either asymptomatic or symptomatic, with a wide range of clinical diseases including erythema infectiosum (fifth disease) in children, chronic arthropathy in adults, hydrops fetalis, and transient aplastic crisis [228-230]. Recently, a B19Vrelated virus was detected in free-ranging and captive new world primates in Central America [231]. Simian parvovirus (SPV, Primate erythroparvovirus 2) shares features with B19V, including its molecular structure and tropism for the bone marrow, but most infections are non-pathogenic except in immunosuppressed or anemic monkeys $[53,54]$. SPV was discovered in 1992 when immunosuppressed macaques developed severe anemia. Histology revealed decreased erythroid and myeloid lineages with occasional intranuclear viral inclusions, and EM showed intranuclear viral particles characteristic of parvoviruses [53]. In 2000, erythroparvoviruses were identified in the serum of captive nonhuman primates with anemia, including rhesus macaque parvovirus (RmPV, Primate erythroparvovirus 3) and pig-tailed macaque parvovirus (PmPV, Primate erythroparvovirus 4) [232].

Bovine parvovirus 3 (BPV3, Ungulate erythroparvovirus 1) was first detected in bovine serum [180], and later in cattle in Brazil [126], but no disease has been associated. Chipmunk parvovirus (ChpPV, Rodent erythroparvovirus 1) was identified in the sera of Manchurian chipmunks in Korea [233], and its NS1 induces apoptosis in COS-7 cells, similar to what has been observed with NS1 of other parvoviruses [234]. No disease has been associated with ChpPV infection.

Seal parvovirus (SePV, Pinniped erythroparvovirus 1) DNA was detected in brain tissue of a harbor seal with non-suppurative meningoencephalitis in the Netherlands [235]. ISH revealed viral NA in the cerebral parenchyma adjacent to the meninges, suggesting a potential association between the virus and lesions. Analysis of archived tissues (1988-2014) from harbor and grey seals demonstrated that SePV DNA was present in both populations [236]. Currently, these findings provide weak evidence to support pathogenicity and are limited by the feasibility of experimental infections of marine mammals (Table 2).

\section{Genus Loriparvovirus}

Slow loris parvovirus 1 (SI.L-PV-1, Primate loriparvovirus 1) DNA was detected in the serum and organs of a captive 22-year-old slow loris, a small nocturnal primate, that was euthanized due to poor condition following diagnosis with histiocytic sarcoma [237]. The virus was detected in banked serum samples of that animal collected over an 8-year period prior to death, demonstrating persistent infection, but samples from 25 other animals yielded negative results [237].

\section{Genus Protoparvovirus}

Members of the genus Protoparvovirus (formerly Parvovirus) package a genome of $\sim 4.5-5.5 \mathrm{kbp}$ and encode two large genes that encode for NS1 and VP1/2 [14]. These viruses infect a wide range of animal hosts and cause a variety of conditions from subclinical to lethal disease (Fig. 2, Table 1) [14]. Viruses include cutavirus (CuV), infecting humans; porcine parvovirus (PPV), infecting pigs; minute virus of mice (MVM), infecting rodents; feline panleukopenia virus (FPV) and canine parvovirus 2 (CPV-2) which infect members of the Order Carnivora, including cats, racoons and mink. CPV-2 infection of rescued, free-ranging Taiwanese pangolins, provides the first evidence of CPV-2 infection in a non-carnivore [238, 239]. CPV-2 arose as a variant of FPV, creating pandemics among dogs, coyotes, and wolves [19], and we will discuss both viruses as a model for understanding emergence and host-switching.

\section{Feline panleukopenia virus (FPV)}

Publications from the $1920-30$ s reported an infectious enteritis in cats and raccoons with a high mortality rate referred to by various names including malignant panleukopenia, infectious agranulocytosis, and more recently, feline panleukopenia [240]. The infectious agent for this disease, named FPV, was first isolated in tissue culture from a captive snow leopard in the 1960s after it was recognized it required dividing cells for replication [241]. Shortly thereafter, additional viruses were isolated from cats and other hosts, and some of those early isolates were used to prepare attenuated viral strains by passaging in tissue culture [242]. Those attenuated viruses were soon included in the standard vaccines that are now recommended for all kittens [243]. Due to the vaccination program, FPV became a less frequent disease in many countries including the UK, Australia, New Zealand, 
and the US. Diseases caused by FPV include enteritis in kittens older than $\sim 6$ weeks (as younger animals are generally protected by maternal immunity), often accompanied by panleukopenia, due to virus replicating in the rapidly dividing cells of the intestinal crypts, bone marrow, and other lymphoid tissues [48, 49]. Another disease outcome is seen when neonatal kittens are infected, where virus infecting the cerebellum causes cerebellar hypoplasia and ataxia [244]. Recent work has revealed the structural features of the FPV capsid [245], the hostantibody responses [246], and the genetic variation in FPV sequences from many parts of the world [87, 233, 247-251]. Those studies have revealed the overall evolution of FPV, and helped to explain processes that underlie viral emergence, viral adaptation, and genetic variation.

\section{Canine parvovirus (CPV-2)}

Canine parvovirus emerged as a new pathogen in dogs during late 1970s as the result of a cross-species transmission event from an FPV-like virus. The successful crossspecies transfer and adaptation to the new canine host involved around six aa changes on the surface of each capsid copy/subunit, which allowed the virus to bind and infect cells using the canine cellular transferrin receptor type-1 [52, 252, 253]. The original strain that emerged in 1978, CPV-2, was replaced one year later by a variant termed CPV-2a, which contained 5 additional mutations in the capsid protein, regaining the feline host range and also likely allowing CPV-2a to infect other hosts including minks, coyotes, foxes, and raccoons. Although CPV-2 and FPV are over 98\% identical in DNA sequence, they differ in host range, antigenic structure, and hemagglutination properties [252, 254]. CPV-2 targets rapidly dividing cells in puppies, including those in intestinal epithelial crypts, bone marrow, lingual epithelium, oral cavity, and cardiac myocytes [50]. After an incubation period of 3-7 days, clinical signs may include vomiting, hemorrhagic diarrhea, depression, lymphopenia, loss of appetite, fever, and dehydration in younger dogs. Infection in neonatal puppies, can result in myocarditis after a few weeks $[48,51,255-260]$. CPV-2 can be fatal when untreated, but infection is prevented by vaccination [260-263]. The emergence of CPV-2 as a pandemic virus in the late 1970s represents one of the few accessible models of a virus jumping to a new host where we can compare in detail the ancestral and descendent viruses to better understand fundamental processes that control host selection, emergence, and viral evolution. After 40 years of viral spread, new sequencing and imaging approaches have revealed natural variants and the capsid features that bind antibodies and the host receptor, leading to viral adaptation and host switching [264-267].

\section{Porcine parvovirus (PPV)}

PPV (Ungulate protoparvovirus 1) causes a series of conditions in fetal pigs termed "SMEDI" (stillbirth, mummification, embryonic death, and infertility). PPV is endemic in most countries, and severe outbreaks can occur in unvaccinated herds that lack maternal immunity. PPV was first detected in the early 1960s in primary porcine kidney and testicle cell cultures used to cultivate hog cholera virus [268]. The virus was only later detected in a series of stillbirths, infertility, and abortions in a pig herd [269]. For more information on PPV, we refer to excellent recent reviews [270, 271].

\section{Minute virus of mice (MVM)}

MVM (Rodent protoparvovirus 1) has been used to better understand parvovirus biology and replication. First discovered in 1966, MVM naturally infects laboratory and wild mice, and hamsters and rats can be experimentally infected [272-274]. Infections are mostly subclinical and clinical disease in mice is generally limited to experimental infections with certain strains of virus. MVM infections can alter T lymphocyte functions [272, 275-277]. Two variant MVM strains were isolated from contaminated cell cultures and named MVMp (for prototype) and MVMi (for immunosuppressive). Experimental infection of adult $\mathrm{BALB} / \mathrm{c}$ and $\mathrm{C} 57 \mathrm{BL} / 6$ mice with either strain is asymptomatic, but MVMi causes growth retardation and failure to develop effective circulating antibody titers against the virus in neonatal mice [278]. The MVM NS1 protein mediates the localization of the viral genome to sites of DNA damage during viral replication [279], and there is a close relationship between viral replication and DNA damage pathways that likely could be seen for other pathogenic parvoviruses as well, especially those that are capable of replicating in low or non-dividing cells, such as the copiparvovirus EqPV-H.

\section{Rat parvoviruses (RPV)}

Rat parvoviruses have been recognized for over 50 years, with Kilham rat virus (KRV) being recovered from rat tumors and $\mathrm{H}-1$ virus $(\mathrm{H}-1)$ from human tumor cell lines in 1959 and 1960, respectively [280, 281]. Rat parvovirus 1 (RPV1) was isolated from infected cell lines in 1998 and rat minute virus (RMV) was detected in naturally infected rats in 2002 [282, 283]. RPV1 infections are generally subclinical, and disease associated with experimental infections varies between serotypes of virus and age of the rat. Natural KRV infection of suckling rats was once reported to result in runting, ataxia, jaundice, and cerebellar hypoplasia, while infection of juvenile rats caused sudden death, scrotal cyanosis, and abdominal swelling [284]. 


\section{Other protoparvoviruses}

Parvoviral DNA was isolated from archived tissues (2000-2013) of stranded southern sea otters and named sea otter parvovirus (SoPV, Carnivore protoparvovirus 2) [285]. PCR analysis of tissues of 69 otters revealed a $61 \%$ DNA prevalence with no change in prevalence rates over time, suggesting SoPV is endemic. DNA was most frequently detected in mesenteric lymph nodes, with much lower frequency in liver, lung, retropharyngeal lymph nodes, and spleen. The association of this virus with clinical disease in otters is unknown and experimental infection studies are unlikely due to its status as threatened subspecies.

Other protoparvovirus DNA has been discovered in dogs, wild wolves, foxes, pigs, bats, primates, and other hosts (Table 1). Canine bufavirus (CBuV, Carnivore protoparvovirus 3) was first detected in samples from three puppies with respiratory disease in Italy in 2011 [286]. The virus is a common component of the canine enteric virome, and viral DNA has been detected in feces of (1) diarrheic dogs in China [287, 288], (2) both healthy and sick dogs in Italy [289] and (3) wild wolves and foxes in Italy [290]. CBuV DNA was also detected in nasal and oropharyngeal swabs and enteric samples of young and adult domestic cats in Italy [291]. Fox parvovirus (FoPV, Carnivore protoparvovirus 4) DNA was detected in the fecal virome of foxes in the Netherlands in 2013 and in foxes in Croatia in 2016, but has not been associated with disease [292, 293]. Porcine bufavirus (PBuV, Ungulate protoparvovirus 2) DNA was detected in feces from domestic pigs with and without posterior paraplegia living at five affected, and one unaffected, farms in Hungary in 2016 [294]. The virus has been detected in diarrheic pigs in China and healthy pigs in the USA, although disease association is unknown [295-298]. California sea lion parvovirus DNA was detected in the mesenteric lymph node of a stranded, free-ranging California sea lion with disseminated granulomatous inflammation and necrotizing steatitis and vasculitis [299]. The clinical significance of this virus, however, remains undetermined as five additional mammalian viruses were also detected in the lymph node and in situ hybridization of multiple tissues was negative.

\section{Genus Tetraparvovirus}

This genus was established in 2014 to recognize viruses discovered through metagenomics analyses (Fig. 2, Table 1). Human parvovirus 4 (PARV4) DNA was isolated from plasma of human patients with acute viral infection syndrome in 2005 [300], although its clinical significance remains undetermined. Porcine parvovirus 2 (PPV2, Ungulate tetraparvovirus 3) DNA was discovered in Myanmar in swine sera in 2001 [301], and more recently in China, Hungary, US, Germany, Japan, and Vietnam [302-307]. A high prevalence of PPV2 DNA was found in archived porcine serum and lung tissue samples collected between 1996 to 2013 in the US, and concurrent porcine circovirus type 2 (PCV2) DNA was seen in $14.3 \%$ of the pigs [186]. Since the prevalence of PPV2 DNA was significantly higher in tissues also containing PCV2 DNA, PPV2 may contribute to PCV-associated disease [186]. In situ PCR showed PPV2 DNA or RNA in lymphocytes in lungs, lymph nodes, and liver, of dead weaned pigs on PCV2-associated PMWS-negative and -positive farms in Hungary [306]. IHC co-staining for T and B lymphocytes, and macrophages, suggested that PPV2 may have a specific tropism for immature B lymphocytes and/or NK cells, but not $\mathrm{T}$ lymphocytes. Attempts to culture the virus in vitro have been unsuccessful and additional studies are needed to reveal any PPV2 disease association, as current evidence is weak (Table 2).

Bovine hokovirus 1 (BPARV4) DNA (species Ungulate tetraparvovirus 1) has been detected in samples of bovine spleen, and porcine parvovirus 3 (PPV3, Ungulate tetraparvovirus 2, formerly known as porcine hokovirus PPARV4) DNA was found in lymph nodes, liver, serum, and nasopharyngeal or fecal swabs of pigs [308]. In 2016, BPARV4 DNA was also detected in blood samples of yaks in China [309]. PPV3 DNA has been detected worldwide in healthy and sick pigs, but has not been linked to disease $[185,305,308,310]$. DNA of the first tetraparvovirus of sheep, ovine hokovirus (OvPARV4, Ungulate teraparvovirus 4), was first isolated in 2011 from ovine liver and spleen samples [311]. Lastly, Eidolon helvum parvovirus 1 (BtPARV4, Chiropteran tetraparvovirus 1) was identified in the blood samples of flying fox bats of West Africa, though its clinical significance remains unclear [99].

\section{Genus Chaphamaparvovirus}

Following the recent ICTV re-classification, this genus has been added under the new Hamaparvovirinae subfamily of Parvoviridae (Fig. 2, Table 1). The name chapparvovirus comes from the host groups in which its members were initially discovered (chiropteran, avian, and porcine), and currently contains 16 species, many recently discovered [20]. Similar to aveparvoviruses, chaphamaparvoviruses do not have a $\mathrm{PLA}_{2}$ domain in their VP proteins [20]. A recent analysis of MKPV identified several additional putative accessory proteins, namely p15, p10, and NS2/NP, whose functions are unknown (Fig. 3) [8].

\section{Mouse kidney parvovirus (MKPV)}

MKPV belongs to the species Rodent chaphamaparvovirus $1[7,8]$. The discovery of MKPV helped resolve a 40-year-old mystery concerning the etiology of a 
condition in laboratory mice known as inclusion body nephritis (IBN), characterized by prominent, homogenous eosinophilic inclusions in the nucleus of renal tubular epithelial cells of immunodeficient mice [7, 312, 313]. The initial discovery of MKPV occurred after an increase in deaths of immunodeficient mice due to kidney failure [7]. Gross lesions included shrunken, pale kidneys, and these kidneys had tubular degermation and necrosis, tubular loss, interstitial fibrosis, and medullary papillary necrosis microscopically. The nuclei of numerous tubular epithelial cells contained large, amphophilic, intranuclear inclusions characteristic of a viral infection, but attempts to identify viral particles with EM were unsuccessful. RNA extraction and sequencing of kidney tissue from affected mice revealed two coding sequences with homology to the typical parvoviral NS and VP proteins [7]. To help fulfill some of Koch's postulates, the authors demonstrated transmission of the virus through co-housing with virus-free mice. Importantly, co-housed mice had detectable MKPV DNA in the serum and urine after 50-80 days [7]. ISH of viral NA showed localization in tubular epithelial cells, and the abundance of the ISH signal correlated with the severity of disease further indicating disease association. Lastly, liquid chromatography-tandem mass spectrometry of affected kidneys revealed MKPV NS1 and VP1 peptides, indicating productive infection. RNA sequencing and mass spectrometry of affected kidney tissue also demonstrated expansion of activated macrophages and development of myofibroblasts in the kidney. Combined, these findings not only provided strong evidence of an etiology for IBN in mice, but also suggest a model of chronic kidney disease in humans (Table 2). Another study demonstrated viral NA in renal tubular epithelial cells, but not in liver or spleen, and combined with their findings of spliced MKPV RNA production in kidney cells only, suggest that that the kidney is the exclusive location for MKPV replication despite detection of DNA in other tissues [8]. While these reports focused on lesions in immunodeficient mice, other studies have shown that histologic lesions associated with MKPV infection of immunocompetent mice were similar, with lymphoplasmacytic tubulointerstitial nephritis with tubular denegation, although with rare intranuclear inclusions [11].

Similar viruses may be widespread in rodents, and a close relative (murine chapparvovirus (MuCPV, classified within the same species) was discovered in the feces of house mice in residential building of New York City [223]. A prevalence study of MKPV in laboratory mice using feces collected over a seven-month period from 78 biomedical research institutions found that $5.1 \%$ of mice tested positive by qPCR and in addition, $23.3 \%$ of pet mice from a pet store local to the authors in the US were also positive for MKPV [8]. These epidemiologic and metagenomic studies demonstrate that these viruses are widely distributed in laboratory, pet, and wild mouse populations around the world.

\section{Tilapia parvovirus (TiPV)}

The partial genome of TiPV was first detected during a metagenomic analysis of crocodile feces in China [2]. After detecting a higher prevalence of this virus in feces of crocodiles fed tilapia versus those fed chicken, TiPV was identified in the intestines of tilapia [2]. TiPV was also detected during a severe mortality event in farmed adult tilapia in China in 2015, using a combination of EM, experimental infection, and ISH [6]. Clinical signs of affected fish included lethargy, anorexia, change in swim behavior, multifocal hemorrhage, and ocular lesions. Microscopically, fish had splenic necrosis, encephalitis, nephritis, hepatitis, and gill branchitis. EM revealed aggregates of non-enveloped capsids of $\sim 30 \mathrm{~nm}$ in diameter in the cytoplasm and nucleus of cells of the heart, spleen, kidneys, brain, and gills. Both positive viral NA hybridization by ISH and viral DNA by PCR were detected at the highest levels in kidney and spleen, and experimental infection studies with purified TiPV from cell culture resulted in similar lesions compared to naturally occurring disease, providing strong evidence of pathogenicity [6] (Table 2). Phylogenetic analysis revealed that TiPV NS1 protein aa sequence was most closely related to porcine parvovirus 7 (PPV7) of the same genus. TiPV is clearly a pathogenic virus in tilapia, an important economic species for aquaculture worldwide, and is the first parvovirus confirmed to infect fish. More recently, TiPV was co-detected with Tilapia lake virus in a natural disease outbreak of farmed tilapia in Thailand, further emphasizing the significance of this pathogen [314].

\section{Other chaphamaparvoviruses}

PPV7 (Ungulate chaphamaparvovirus 1) was first discovered in pooled rectal swabs of adult pigs in the US in 2016, and has subsequently been detected in China, Korea, Poland, Sweden, and Brazil [315-320]. Some studies suggest that this virus has a more rapid evolutionary rate compared to other PPV genotypes [321]. However, a direct link between infection and clinical disease has not been established.

Two novel parvoviruses were detected in stool samples from dogs suffering from an infectious diarrhea outbreak in the US in 2017 [322]. These closely related viruses, called Cachavirus (CachaV) 1 and -2 (Carnivore chaphamaparvovirus 1) were subsequently demonstrated in the stool of both diarrheic and healthy dogs in China and Italy, suggesting that those are not a direct cause of the disease [323, 324]. CachaV DNA was also detected in 
the feces of two diarrheic cats in China, but there was no statistically significant association between the presence of the virus and clinical signs [325].

Identified avian chaphamaparvoviruses include turkey parvovirus 2 (TPV2, Galliform chaphamaparvovirus 1) detected in feces of a 1-year-old turkey with diarrhea in Hungary [326], and chicken chapparvovirus 2 (ChikPV2, Galliform chaphamaparvovirus 2) identified in feces of chickens that were either sick with malabsorption syndrome or healthy [327]. There were no statistically significant differences in the distribution of viral sequence reads identified in either healthy or sick birds. Discoveries of chapparvoviruses in other bird species include parakeets [328], peafowls [329], and red-crowned cranes [127]. A study of Canadian ducks detected duck-associated chapparvovirus (DAC) in paired oropharyngeal and cloacal swabs of apparently healthy ducks and Galliform chaphamaparvovirus 3 in a gull [330].

Many chapparvovirus sequences have been detected in metagenomic studies of bat viromes, including Desmodus rotundus chapparvovirus (DrPV-1, Chiropteran chaphamaparvovirus 1), which was identified in kidney tissue from vampire bats in Brazil [331]. Tasmanian devilassociated chapparvovirus 1, 2, and 6 (TdChPV, Dasyurid chaphamaparvovirus 1-3) were identified during a metagenomic analysis of the Tasmanian devil virome in 2019 [332]. Capuchin kidney parvovirus (CKPV, Primate chaphamaparvovirus 1) was detected in the kidney of a wild capuchin monkey and had a high level of identity with MKPV [8]. A novel chaphamaparvovirus called fechavirus (FChPV, Carnivore chaphamaparvovirus 2) was identified in six cats during an outbreak of vomiting and diarrhea in a system of shelters in Canada in the same study that also identified three novel bocaparvoviruses [151]. Psittacara leucophthalmus chapparvovirus (PlChPV, Psittacine chaphamaparvovirus 1) was identified in fecal specimens of wild birds in Brazil [328]. Bearded dragon chaphamaparvovirus (BDchPV) was identified along with a novel circovirus during a meta-transcriptomic investigation of a mass mortality and morbidity event in a bearded dragon colony associated with extensive proliferation of the respiratory epithelium [333]. Lastly, a rat parvovirus 2 (RPV2, Rodent chaphamaparvovirus 2) has been identified in a metagenomics study of adult rats in China in 2016 [334].

\section{Animal parvoviruses as therapeutics for human diseases}

As mentioned previously, human AAVs have received high interest because of their use as powerful tools for gene therapy in humans, since the first use of an AAV vector for gene delivery in 1984. After a long period of development, a number of recombinant (r)AAVs have recently been approved for use in humans. Alipogene tiparvovec (Glybera), an AAV-based gene therapy treatment for lipase deficiency, was the first approved rAAV gene therapy for use in humans and was approved by the European Medicines Agency in 2012 [335]. Voretigene neparvovec-rzyl (Luxturna), an rAAV therapy to treat RPE65 mutation-associated inherited retinal disease was approved in the US in 2017 [336]. However, a challenge with using human AAVs for gene therapy is the presence of pre-existing anti-AAV capsid antibodies in humans that block the viruses [337]. Some AAVs from other hosts may also be affected by immunity in humans. For example, AAV8 from Rhesus macaque is blocked by neutralizing antibodies in $10-40 \%$ of people in many populations, depending on the geographical region [337, 338]. To reduce the likelihood of pre-existing immunity in humans, the use of AAV capsids from other animals which do not normally infect humans and induce pre-existing immunity are being explored. For example, porcine-derived rAAVs successfully transduce mouse tissues with a similar efficiency as traditional AAVs, and were not neutralized by pooled human immunoglobulin G [337, 339]. Similarly, the bat AAV strain $10 \mathrm{HB}$ has been proposed as a possible platform for carrying AAV2 vector genomes given the lack of anti-viral antibodies in human sera [221, 222].

Other parvoviruses have also been proposed for human gene therapy. For example, bocaviruses package an approximately $10 \%$ larger genome than AAVs [340]. Gorilla bocavirus 1 (GBoV1) from gorillas [341], has been suggested as a gene therapy delivery vector instead of HBoV1 [342]. HBoV1, which is associated with respiratory disease in humans, is valued as a gene therapy vector because of its specific tropism for the apical side of polarized human airway epithelial cells, thus, providing a therapeutic option for diseases such as cystic fibrosis [33, 343]. GBoV1, like HBoV1, is also able to infect the apical side of polarized human airway epithelial cells and appears less susceptible to neutralization by human immunoglobulins [340].

Autonomous animal parvoviruses are also being developed as human anti-cancer agents and the role of parvoviruses in oncolytic therapy has been recently reviewed elsewhere [344]. Rodent parvoviruses, and in particular the non-pathogenic $\mathrm{H} 1$, have showed promising results as oncolytic viruses due to their high safety profile and natural oncotropism. H1 infection of cancer cells results in cell lysis and secondary stimulation of the immune response through the release of danger-associated molecular patterns (DAMPs), viral pathogen-associated molecular patterns (PAMPs), and tumor-associated antigens [345]. 


\section{Conclusion}

The number of parvoviruses and parvoviral sequences has increased dramatically in recent years due to improvements in viral discovery approaches and studies in domestic animals and many wild species, including some that are critically endangered. A better understanding of these parvovirus infections, and identification of those with pathogenic potential, will help to explain the etiology of many diseases, and might increase the chances of rescuing those animal species that are endangered. Lastly, as shown by the recent emergence and widespread impact of SARS-CoV-2 as well as by the pandemic emergence of canine parvovirus in the 1970s, the significance of any newly discovered virus is not always obvious at first. This review clearly shows that we can expect the same for parvoviruses, since new pathogenic viruses continue to be identified around 100 years after the first parvovirus diseases were reported.

\begin{abstract}
Abbreviations
aa: Amino acid; AAV: Adeno-associated virus; AD: Aleutian disease; CSF: Cerebrospinal fluid; DDR: DNA damage response; EM: Electron microscopy; ICVT: International Committee on Taxonomy of Viruses; IHC: Immunohistochemistry; ISH: In situ hybridization; ITR: Inverted terminal repeat; NA: Nucleic acid; NGS: Next generation sequencing; NS: Nonstructural protein; ORF: Open reading frame; PLA2: Phospholipase A2; rAAV: Recombinant adeno-associated virus; Rep: Replication; RSS: Runting and stunting syndrome; SBDS: Short beak and dwarfism syndrome; SF3: Super family 3; ss: Single stranded; US: United States of America; VP: Viral protein.
\end{abstract}

\section{Acknowledgements}

Not applicable.

\section{Authors' contributions}

MCJ, JET, and GRVdW participated in the review design, and drafted the manuscript together with RAAL. CRP provided critical review and revised the manuscript. All authors read and approved the final manuscript.

\section{Funding}

This work was supported by the National Institutes of Health (NIH) under following awards: the Office of the Director under Award number T320D0011000 to MCJ and the National Institute of Allergy and Infectious Diseases (NIAID) under Award number K08AI141767 to JET, Award number R01Al092571 to CRP, and Award number 3R01Al092571-08W1 to RAAL; an Agriculture \& Food Research Initiative Competitive Grant number 2020-6701531297 from the USDA National Institute of Food and Agriculture to GRVdW; and a Harry M. Zweig Memorial Fund for Equine Research grant to GRVdW. The content is solely the responsibility of the authors and does not necessarily represent the official views of the NIH and the USDA.

\section{Availability of data and materials}

Not applicable.

\section{Declarations}

Ethics approval and consent to participate Not applicable.

\section{Consent for publication}

All authors approved the manuscript for publication.

\section{Competing interests}

The authors declare that they have no competing interests.
Received: 16 July 2021 Accepted: 8 October 2021

Published online: 24 October 2021

\section{References}

1. Vibin J, Chamings A, Klaassen M, Bhatta TR, Alexandersen S. Metagenomic characterisation of avian parvoviruses and picornaviruses from Australian wild ducks. Sci Rep. 2020;10(1):12800.

2. Du J, Wang W, Chan JF-W, Wang G, Huang Y, Yi Y, et al. Identification of a Novel Ichthyic Parvovirus in Marine Species in Hainan Island, China. Front Microbiol. 2019;10:2815.

3. Divers TJ, Tennant BC, Kumar A, McDonough S, Cullen J, Bhuva N, et al. New parvovirus associated with serum hepatitis in horses after inoculation of common biological product. Emerg Infect Dis. 2018;24(2):303-10.

4. Tomlinson JE, Jager M, Struzyna A, Laverack M, Fortier LA, Dubovi E, et al. Tropism, pathology, and transmission of equine parvovirus-hepatitis. Emerging Microbes \& Infections. 2020;9(1):651-63.

5. Vengust $M$, Jager MC, Zalig V, Cociancich V, Laverack M, Renshaw RW, et al. First report of equine parvovirus-hepatitis-associated Theiler's disease in Europe. Equine Veterinary Journal [Internet]. [cited $2020 \mathrm{Sep}$ 28];n/a(n/a). Available from: http://beva.onlinelibrary.wiley.com/doi/ abs/https://doi.org/10.1111/evj.13254

6. Liu W, Zhang Y, Ma J, Jiang N, Fan Y, Zhou Y, et al. Determination of a novel parvovirus pathogen associated with massive mortality in adult tilapia. PLoS Pathogens. 2020;16(9):e1008765.

7. Roediger B, Lee Q, Tikoo S, Cobbin JCA, Henderson JM, Jormakka M, et al. An atypical parvovirus drives chronic tubulointerstitial nephropathy and kidney fibrosis. Cell. 2018;175(2):530-543.e24.

8. Lee Q, Padula MP, Pinello N, Williams SH, O'Rourke MB, Fumagalli MJ, et al. Murine and related chapparvoviruses are nephro-tropic and produce novel accessory proteins in infected kidneys. PLoS Pathog. 2020;16(1):e1008262.

9. Ge Z, Carrasco SE, Feng Y, Bakthavatchalu V, Annamalai D, Kramer $\mathrm{R}$, et al. Identification of a new strain of mouse kidney parvovirus associated with inclusion body nephropathy in immunocompromised laboratory mice. Emerg Microbes Infect. 2020;9(1):1814-23.

10. Alex CE, Kubiski SV, Li L, Sadeghi M, Wack RF, McCarthy MA, et al. Amdoparvovirus infection in Red Pandas ( Ailurus fulgens ). Vet Pathol. 2018;55(4):552-61.

11. Edmondson EF, Hsieh W-T, Kramer JA, Breed MW, Roelke-Parker ME, Stephens-Devalle J, et al. Naturally acquired mouse kidney parvovirus infection produces a persistent interstitial nephritis in immunocompetent laboratory mice. Vet Pathol. 2020;57(6):915-25.

12. Pfankuche V, Hahn K, Bodewes R, Hansmann F, Habierski A, Haverkamp A-K, et al. Comparison of different in situ hybridization techniques for the detection of various RNA and DNA viruses. Viruses. 2018;10(7):384.

13. Fredericks DN, Relman DA. Sequence-based identification of microbial pathogens: a reconsideration of Koch's postulates. Clin Microbiol Rev. 1996;9(1):18-33.

14. Cotmore SF, Tattersall P. Parvoviruses: Small Does Not Mean Simple. Annu Rev Virol. 2014;1(1):517-37.

15. Kailasan S, Agbandje-MCKenna M, Parrish CR. Parvovirus family conundrum: What makes a killer? Annu Rev Virol. 2015;2(1):425-50.

16. Tu M, Liu F, Chen S, Wang M, Cheng A. Role of capsid proteins in parvoviruses infection. Virol J [Internet]. 2015 [cited 2019 May 29];12. Available from: https://www.ncbi.nlm.nih.gov/pmc/articles/PMC45 24367/

17. Mietzsch M, Pénzes JJ, Agbandje-McKenna M. Twenty-Five years of structural parvovirology. Viruses. 2019;11(4):362.

18. Gallinella G. New insights into parvovirus research. Viruses. 2019;11(11):1053.

19. Cotmore SF, Agbandje-McKenna M, Chiorini JA, Mukha DV, Pintel DJ, Qiu J, et al. The family Parvoviridae. Arch Virol. 2014;159(5):1239-47.

20. Pénzes JJ, Söderlund-Venermo M, Canuti M, Eis-Hübinger AM, Hughes J, Cotmore SF, et al. Reorganizing the family Parvoviridae: a revised taxonomy independent of the canonical approach based on host association. Arch Virol. 2020;165(9):2133-46.

21. Fields BN, Knipe DM, Howley PM, Griffin DE. Fields virology. Philadelphia: Lippincott Williams \& Wilkins; 2001. 
22. Cotmore SF, Tattersall P. Genome packaging sense is controlled by the efficiency of the nick site in the right-end replication origin of parvoviruses minute virus of mice and LullI. JVI. 2005;79(4):2287-300.

23. Bates RC, Snyder CE, Banerjee PT, Mitra S. Autonomous parvovirus Lull encapsidates equal amounts of plus and minus DNA strands. J Virol. 1984;49(2):319-24.

24. Chen AY, Qiu J. Parvovirus infection-induced cell death and cell cycle arrest. Futur Virol. 2010;5(6):731-43.

25. Gordon JC, Angrick EJ. Canine parvovirus: environmental effects on infectivity. Am J Vet Res. 1986;47(7):1464-7.

26. Fields BN. Fields virology. 6th ed. Knipe DM, Howley PM, editors. Philadelphia: Wolters Kluwer Health/Lippincott Williams \& Wilkins; 2013.

27. Chen KC, Shull BC, Moses EA, Lederman M, Stout ER, Bates RC. Complete nucleotide sequence and genome organization of bovine parvovirus. J Virol. 1986;60(3):1085-97.

28. Zádori Z, Szelei J, Tijssen P. SAT: a late NS protein of porcine parvovirus. J Virol. 2005;79(20):13129-38.

29. Ruiz Z, Mihaylov IS, Cotmore SF, Tattersall P. Recruitment of DNA replication and damage response proteins to viral replication centers during infection with NS2 mutants of Minute Virus of Mice (MVM). Virology. 2011;410(2):375-84.

30. Sonntag F, Köther K, Schmidt K, Weghofer M, Raupp C, Nieto K, et al. The assembly-activating protein promotes capsid assembly of different adeno-associated virus serotypes. J Virol. 2011;85(23):12686-97.

31. Zhi N, Mills IP, Lu J, Wong S, Filippone C, Brown KE. Molecular and functional analyses of a human parvovirus B19 infectious clone demonstrates essential roles for NS1, VP1, and the 11-kilodalton protein in virus replication and infectivity. J Virol. 2006;80(12):5941-50.

32. Oleksiewicz MB, Costello F, Huhtanen M, Wolfinbarger JB, Alexandersen S, Bloom ME. Subcellular localization of Aleutian mink disease parvovirus proteins and DNA during permissive infection of Crandell feline kidney cells. J Virol. 1996;70(5):3242-7.

33. Deng X, Yan Z, Cheng F, Engelhardt JF, Qiu J. Replication of an Autonomous Human Parvovirus in Non-dividing Human Airway Epithelium Is Facilitated through the DNA Damage and Repair Pathways. PLOS Pathogens. 2016;12(1):e1005399.

34. Deng X, Xu P, Zou W, Shen W, Peng J, Liu K, et al. DNA damage signaling is required for replication of human bocavirus 1 DNA in dividing HEK293 cells. McFadden G, editor. J Virol. 2017;91(1):e01831-16.

35. Adeyemi RO, Landry S, Davis ME, Weitzman MD, Pintel DJ. Parvovirus Minute Virus of Mice Induces a DNA Damage Response That Facilitates Viral Replication. PLoS Pathog. 2010 [cited 2020];6(10).

36. Luo Y, Qiu J. Parvovirus infection-induced DNA damage response. Future Virol. 2013;8(3):245-57.

37. Scarth JA, Patterson MR, Morgan EL, Macdonald A. The human papilIomavirus oncoproteins: a review of the host pathways targeted on the road to transformation. J Gener Virol. 2021 [cited 2021];102(3). https:// doi.org/10.1099/jgv.0.001540

38. Full F, Ensser A. Early nuclear events after herpesviral infection. JCM. 2019;8(9):1408.

39. Luftig MA. Viruses and the DNA damage response: activation and antagonism. Ann Rev Virol. 2014;1(1):605-25.

40. Weitzman MD, Fradet-Turcotte A. Virus DNA Replication and the Host DNA Damage Response. Annu Rev Virol. 2018;5(1):141-64.

41. Söderlund-Venermo M. Emerging human parvoviruses: the rocky road to fame. Annu Rev Virol. 2019;6(1):annurev-virology-092818-015803.

42. Qiu J, Söderlund-Venermo M, Young NS. Human Parvoviruses. Clin Microbiol Rev. 2017:30(1):71

43. Alexandersen S. Acute interstitial pneumonia in mink kits: experimental reproduction of the disease. Vet Pathol. 1986;23(5):579-88.

44. Eklund CM, Hadlow WJ, Kennedy RC, Boyle CC, Jackson TA. Aleutian disease of mink: properties of the etiologic agent and the host responses. J Infect Dis. 1968;118(5):510-26.

45. Berns KI. Parvovirus replication. Microbiol Rev. 1990;54(3):316-29.

46. Chen AY, Guan W, Lou S, Liu Z, Kleiboeker S, Qiu J. Role of Erythropoietin receptor signaling in parvovirus B19 replication in human erythroid progenitor cells. J Virol. 2010;84(23):12385-96.

47. Chen AY, Kleiboeker S, Qiu J. Productive Parvovirus B19 Infection of Primary Human Erythroid Progenitor Cells at Hypoxia Is Regulated by STAT5A and MEK Signaling but not HIFa. PLOS Pathog. 2011:7(6):e1002088
48. Parrish CR. Pathogenesis of feline panleukopenia virus and canine parvovirus. Baillieres Clin Haematol. 1995;8(1):57-71.

49. Fowler EH, Rohovsky MW. Enzyme histochemistry of the small intestine in germfree and specific-pathogen-free cats inoculated with feline infectious enteritis (feline panleukopenia) virus. Am J Vet Res. 1970;31(11):2055-60.

50. Ford J, McEndaffer L, Renshaw R, Molesan A, Kelly K. Parvovirus Infection Is Associated With Myocarditis and Myocardial Fibrosis in Young Dogs. Vet Pathol. 2017;54(6):964-71.

51. Nelson DT, Eustis SL, McAdaragh JP, Stotz I. Lesions of spontaneous canine viral enteritis. Vet Pathol. 1979;16(6):680-6.

52. Truyen U, Parrish CR. Canine and feline host ranges of canine parvovirus and feline panleukopenia virus: distinct host cell tropisms of each virus in vitro and in vivo. J Virol. 1992;66(9):5399-408.

53. O'Sullivan MG, Anderson DC, Fikes JD, Bain FT, Carlson CS, Green SW, et al. Identification of a novel simian parvovirus in cynomolgus monkeys with severe anemia. A paradigm of human B19 parvovirus infection. J Clin Invest. 1994;93(4):1571-6.

54. O'Sullivan MG, Anderson DK, Goodrich JA, Tulli H, Green SW, Young NS, et al. Experimental infection of cynomolgus monkeys with simian parvovirus. J Virol. 1997;71(6):4517-21.

55. Mori S, Wolfinbarger JB, Miyazawa M, Bloom ME. Replication of Aleutian mink disease parvovirus in lymphoid tissues of adult mink: involvement of follicular dendritic cells and macrophages. J Virol. 1991;65(2):952-6.

56. Kanno H, Wolfinbarger JB, Bloom ME. Aleutian mink disease parvovirus infection of mink macrophages and human macrophage cell line U937: demonstration of antibody-dependent enhancement of infection. J Virol. 1993;67(12):7017-24.

57. Dworak LJ, Wolfinbarger JB, Bloom ME. Aleutian mink disease parvovirus infection of $\mathrm{K} 562$ cells is antibody-dependent and is mediated via an Fc(gamma)RII receptor. Arch Virol. 1997;142(2):363-73.

58. Cho HJ, Ingram DG. Pathogenesis of aleutian disease of mink: nature of the antiglobulin reaction and elution of antibody from erythrocytes and glomeruli of infected mink. Infect Immun. 1973;8(2):264-71

59. Porter DD, Larsen AE, Porter HG. The pathogenesis of Aleutian disease of mink. 3. Immune complex arteritis. Am J Pathol. 1973;71(2):331-44.

60. Wu Z, Lu L, Du J, Yang L, Ren X, Liu B, et al. Comparative analysis of rodent and small mammal viromes to better understand the wildlife origin of emerging infectious diseases. Microbiome. 2018;6(1):178.

61. Clemens DL, Wolfinbarger JB, Mori S, Berry BD, Hayes SF, Bloom ME. Expression of Aleutian mink disease parvovirus capsid proteins by a recombinant vaccinia virus: self-assembly of capsid proteins into particles. J Virol. 1992;66(5):3077-85.

62. Qiu J, Cheng F, Burger LR, Pintel D. The transcription profile of aleutian mink disease virus in CRFK cells is generated by alternative processing of pre-mRNAs produced from a single promoter. J Virol. 2006;80(2):654-62.

63. Bloom ME, Alexandersen S, Perryman S, Lechner D, Wolfinbarger JB Nucleotide sequence and genomic organization of Aleutian mink disease parvovirus (ADV): sequence comparisons between a nonpathogenic and a pathogenic strain of ADV. J Virol. 1988;62(8):2903-15.

64. Schuierer S, Bloom ME, Kaaden OR, Truyen U. Sequence analysis of the lymphotropic Aleutian disease parvovirus ADV-SL3. Arch Virol. 1997;142(1):157-66

65. Li Y, Huang J, Jia Y, Du Y, Jiang P, Zhang R. Genetic characterization of Aleutian mink disease viruses isolated in China. Virus Genes. 2012:45(1):24-30

66. Gorham JR, Leader RW, Henson JB. The experimental transmission of a virus causing hypergammaglobulinemia in mink: sources and modes of infection*. J Infect Dis. 1964;114(4):341-5.

67. Hartsough GR, Gorham JR. Aleutian disease in mink. Natl Fur News. 1956:28:10-1.

68. Porter HG, Porter DD, Larsen AE. Aleutian disease in ferrets. Infect Immun. 1982;36(1):379-86.

69. Oie KL, Durrant G, Wolfinbarger JB, Martin D, Costello F, Perryman S, et al. The relationship between capsid protein (VP2) sequence and pathogenicity of Aleutian mink disease parvovirus (ADV): a possible role for raccoons in the transmission of ADV infections. J Virol. 1996:70(2):852-61. 
70. Mañas S, Ceña JC, Ruiz-Olmo J, Palazón S, Domingo M, Wolfinbarger $J B$, et al. Aleutian mink disease parvovirus in wild riparian carnivores in Spain. J Wildl Dis. 2001;37(1):138-44.

71. Allender MC, Schumacher J, Thomas KV, McCain SL, Ramsay EC, James EW, et al. Infection with Aleutian disease virus-like virus in a captive striped skunk. J Am Vet Med Assoc. 2008;232(5):742-6.

72. Knuuttila A, Aaltonen K, Virtala A-MK, Henttonen H, Isomursu M, Leimann $A$, et al. Aleutian mink disease virus in free-ranging mustelids in Finland - a cross-sectional epidemiological and phylogenetic study. J Gener Virol. 2015;96(6):1423-35.

73. Canuti M, Whitney HG, Lang AS. Amdoparvoviruses in small mammals: expanding our understanding of parvovirus diversity, distribution, and pathology. Front Microbiol [Internet]. 2015 [cited 2021 May 28];6. Available from: https://www.ncbi.nlm.nih.gov/pmc/articles/PMC4600916/

74. Canuti M, McDonald E, Graham SM, Rodrigues B, Bouchard É, Neville R, et al. Multi-host dispersal of known and novel carnivore amdoparvoviruses. Virus Evol. 2020;6(2):veaa072.

75. Jepsen JR, d'Amore F, Baandrup U, Clausen MR, Gottschalck E, Aasted B. Aleutian mink disease virus and humans. Emerg Infect Dis. 2009;15(12):2040-2

76. Hadlow WJ, Race RE, Kennedy RC. Royal pastel mink respond variously to inoculation with Aleutian disease virus of low virulence. J Virol. 1984;50(1):38-41.

77. Alexandersen S, Bloom ME, Wolfinbarger J, Race RE. In situ molecular hybridization for detection of Aleutian mink disease parvovirus DNA by using strand-specific probes: identification of target cells for viral replication in cell cultures and in mink kits with virus-induced interstitial pneumonia. J Virol. 1987;61(8):2407-19.

78. Park GS, Best SM, Bloom ME. Two mink parvoviruses use different cellular receptors for entry into CRFK cells. Virology. 2005;340(1):1-9.

79. Prieto A, Fernández-Antonio R, Díaz-Cao JM, López G, Díaz P, Alonso JM, et al. Distribution of Aleutian mink disease virus contamination in the environment of infected mink farms. Vet Microbiol. 2017;1(204):59-63.

80. Ryt-Hansen P, Hagberg EE, Chriél M, Struve T, Pedersen AG, Larsen LE, et al. Global phylogenetic analysis of contemporary aleutian mink disease viruses (AMDVs). Virol J [Internet]. 2017 Nov 22 [cited 2021 May 28];14. Available from: https://www.ncbi.nlm.nih.gov/pmc/articles/ PMC5700682

81. Hagberg EE, Pedersen AG, Larsen LE, Krarup A. Evolutionary analysis of whole-genome sequences confirms inter-farm transmission of Aleutian mink disease virus. J Gener Virol. 2017;98(6):1360-71.

82. Knuuttila A, Uzcátegui N, Kankkonen J, Vapalahti O, Kinnunen P. Molecular epidemiology of Aleutian mink disease virus in Finland. Vet Microbiol. 2009;133(3):229-38.

83. Leimann A, Knuuttila A, Maran T, Vapalahti O, Saarma U. Molecular epidemiology of Aleutian mink disease virus (AMDV) in Estonia, and a global phylogeny of AMDV. Virus Res. 2015;199:56-61.

84. Kowalczyk M, Horecka B, Jakubczak A. Aleutian Mink Disease Virus in the breeding environment in Poland and its place in the global epidemiology of AMDV. Virus Res. 2019;270:197665.

85. Prieto A, Fernández-Antonio R, López-Lorenzo G, Díaz-Cao JM, LópezNovo C, Remesar S, et al. Molecular epidemiology of Aleutian mink disease virus causing outbreaks in mink farms from Southwestern Europe: a retrospective study from 2012 to 2019. J Vet Sci. 2020;21(4):e65.

86. Virtanen J, Smura T, Aaltonen K, Moisander-Jylhä A-M, Knuuttila A, Vapalahti $\mathrm{O}$, et al. Co-circulation of highly diverse Aleutian mink disease virus strains in Finland. J Gener Virol. 2019;100(2):227-36.

87. Canuti M, Todd M, Monteiro P, Van Osch K, Weir R, Schwantje H, et al. Ecology and infection dynamics of multi-host amdoparvoviral and protoparvoviral carnivore pathogens. Pathogens. 2020;9(2):124.

88. Shao X-Q, Wen Y-J, Ba H-X, Zhang X-T, Yue Z-G, Wang K-J, et al. Novel amdoparvovirus infecting farmed raccoon dogs and arctic foxes. Emerg Infect Dis. 2014;20(12):2085-8.

89. Canuti M, Doyle HE, Britton A, Lang AS. Full genetic characterization and epidemiology of a novel amdoparvovirus in striped skunk (Mephitis mephitis). Emerg Microbes Infect. 2017;6(5):e30.

90. Pennick KE, Latimer KS, Brown CA, Hayes JR, Sarver CF. Aleutian Disease in Two Domestic Striped Skunks (Mephitis mephitis). Vet Pathol. 2007;44(5):687-90.

91. Britton AP, Redford T, Bidulka JJ, Scouras AP, Sojonky KR, Zabek E, et al. Beyond rabies: are free-ranging skunks (Mephitis mephitis) in British
Columbia Reservoirs of Emerging Infection? Transbound Emerg Dis. 2017;64(2):603-12.

92. Nituch LA, Bowman J, Wilson PJ, Schulte-Hostedde Al. Aleutian mink disease virus in striped skunks (Mephitis mephitis): Evidence for crossspecies spillover. J Wildl Dis. 2015;51(2):389-400.

93. Giannitti F, Sadeghi M, Delwart E, Schwabenlander M, Foley J. Aleutian disease virus-like virus (Amdoparvovirus sp.) infecting free-ranging striped skunks (Mephitis mephitis) in the Midwestern USA. jwdi. 2018:54(1):186-8.

94. Woolf A, Gremillion-Smith C. Pathologic findings in rabies-suspect, random-source, and accidentally killed skunks. J Am Vet Med Assoc. 1986;189(9):1089-91.

95. LaDouceur EEB, Anderson M, Ritchie BW, Ciembor P, Rimoldi G, Piazza $M$, et al. Aleutian disease: an emerging disease in free-ranging striped skunks (Mephitis mephitis) from California. Vet Pathol. 2015;52(6):1250-3.

96. Glueckert E, Clifford DL, Brenn-White M, Ochoa J, Gabriel M, Wengert $\mathrm{G}$, et al. Endemic Skunk amdoparvovirus in free-ranging striped skunks (Mephitis mephitis) in California. Transbound Emerg Dis. 2019;66(6):2252-63.

97. Glatston A, Wei F, Than Zaw (IUCN SSC Cat SG / Wildlife Conservation Society (WCS) MP, Sherpa AP. IUCN Red List of Threatened Species: Ailurus fulgens. IUCN Red List of Threatened Species [Internet]. 2015 [cited 2021]; Available from: https://www.iucnredlist.org/en

98. Li L, Pesavento PA, Woods L, Clifford DL, Luff J, Wang C, et al. Novel amdovirus in gray foxes. Emerg Infect Dis. 2011;17(10):1876-8.

99. Canuti M, Eis-Huebinger AM, Deijs M, de Vries M, Drexler JF, Oppong SK, et al. Two novel parvoviruses in frugivorous New and Old World bats. PLOS ONE. 2011;6(12):e29140.

100. Kapgate SS, Kumanan K, Vijayarani K, Barbuddhe SB. Avian parvovirus: classification, phylogeny, pathogenesis and diagnosis. Avian Pathol. 2018:47(6):536-45.

101. Zsak L, Strother KO, Day JM. Development of a polymerase chain reaction procedure for detection of chicken and turkey parvoviruses. Avian Dis. 2009;53(1):83-8.

102. Bidin M, Lojkić I, Bidin Z, Tiljar M, Majnarić D. Identification and phylogenetic diversity of parvovirus circulating in commercial chicken and turkey flocks in Croatia. Avian Dis. 2011;55(4):693-6.

103. Palade EA, Kisary J, Benyeda Z, Mándoki M, Balka G, Jakab C, et al. Naturally occurring parvoviral infection in Hungarian broiler flocks. Avian Pathol. 2011:40(2):191-7.

104. Palade EA, Demeter Z, Hornyák Á, Nemes C, Kisary J, Rusvai M. High prevalence of turkey parvovirus in Turkey flocks from hungary experiencing enteric disease syndromes. Avian Dis. 2011;55(3):468-75.

105. Domanska-Blicharz K, Jacukowicz A, Lisowska A, Minta Z. Genetic characterization of parvoviruses circulating in turkey and chicken flocks in Poland. Arch Virol. 2012;157(12):2425-30.

106. Koo B-S, Lee H-R, Jeon E-O, Han M-S, Min K-C, Lee S-B, et al. Genetic characterization of three novel chicken parvovirus strains based on analysis of their coding sequences. Avian Pathol. 2015;44(1):28-34.

107. Nuñez LFN, Santander Parra SH, Mettifogo E, Astolfi-Ferreira CS, Piantino Ferreira AJ. Isolation and molecular characterisation of chicken parvovirus from Brazilian flocks with enteric disorders. Br Poult Sci. 2015:56(1):39-47.

108. Devaney R, Trudgett J, Trudgett A, Meharg C, Smyth V. A metagenomic comparison of endemic viruses from broiler chickens with runting-stunting syndrome and from normal birds. Avian Pathol. 2016:45(6):616-29.

109. Feng B, Xie Z, Deng X, Xie L, Xie Z, Huang L, et al. Genetic and phylogenetic analysis of a novel parvovirus isolated from chickens in Guangxi. China Arch Virol. 2016;161(11):3285-9.

110. Zhang Y, Feng B, Xie Z, Deng X, Zhang M, Xie Z, et al. Epidemiological Surveillance of Parvoviruses in Commercial Chicken and Turkey Farms in Guangxi, Southern China, During 2014-2019. Front Vet Sci. 2020;7:561371.

111. Pradeep M, Reddy MR, Kannaki TR. Molecular identification and characterization of chicken parvovirus from Indian Chicken and Association with Runting and Stunting Syndrome. Indian J Anim Res. 2020:54(12):1517-24

112. la Torre DD, Nuñez LFN, Puga B, Parra SHS, Astolfi-Ferreira CS, Ferreira AJP. Molecular Diagnostic of Chicken Parvovirus (ChPV) Affecting Broiler Flocks in Ecuador. Braz J Poult Sci. 2018;20:643-50. 
113. Mettifogo E, Nuñez LFN, Chacón JL, Santander Parra SH, Astolfi-Ferreira CS, Jerez JA, et al. Emergence of enteric viruses in production chickens is a concern for avian health. ScientificWorldJournal. 2014;2014:450423.

114. Finkler F, Lima DA, Cerva C, Moraes LB, Cibulski SP, Teixeira TF, et al. Chicken parvovirus and its associations with malabsorption syndrome. Res Vet Sci. 2016;107:178-81.

115. Nuñez LFN, Sá LRM, Parra SHS, Astolfi-Ferreira CS, Carranza C, Ferreira AJP. Molecular detection of chicken parvovirus in broilers with enteric disorders presenting curving of duodenal loop, pancreatic atrophy, and mesenteritis. Poult Sci. 2016;95(4):802-10.

116. Day JM, Zsak L. Determination and analysis of the full-length chicken parvovirus genome. Virology. 2010;399(1):59-64.

117. Pantin-Jackwood MJ, Day JM, Jackwood MW, Spackman E. Enteric viruses detected by molecular methods in commercial chicken and turkey flocks in the United States between 2005 and 2006. Avian Dis. 2008:52(2):235-44.

118. Domańska-Blicharz K, Bocian $Ł$, Lisowska A, Jacukowicz A, Pikuła A, Minta Z. Cross-sectional survey of selected enteric viruses in Polish turkey flocks between 2008 and 2011. BMC Vet Res. 2017;13(1):108.

119. Murgia MV, Rauf A, Tang Y, Gingerich E, Lee C-W, Saif YM. Prevalence of parvoviruses in commercial Turkey flocks. Avian Dis. 2012;56(4):744-9.

120. Otto P, Liebler-Tenorio EM, Elschner M, Reetz J, Löhren U, Diller R. Detection of rotaviruses and intestinal lesions in broiler chicks from flocks with runting and stunting syndrome (RSS). Avian Dis. 2006;50(3):411-8.

121. Smyth JA, Connor TJ, McNeilly F, Moffet DA, Calvert VM, McNulty MS. Studies on the pathogenicity of enterovirus-like viruses in chickens. Avian Pathol. 2007;36(2):119-26.

122. Kang K-I, El-Gazzar M, Sellers HS, Dorea F, Williams SM, Kim T, et al. Investigation into the aetiology of runting and stunting syndrome in chickens. Avian Pathol. 2012;41(1):41-50.

123. N. Nuñez LF, Santander-Parra SH, De la Torre DI, Sá LRM de, Buim MR Astolfi-Ferreira CS, et al. Molecular characterization and pathogenicity of chicken parvovirus (ChPV) in specific pathogen-free chicks infected experimentally. Pathogens. 2020;9(8):606.

124. Barnes H, Guy J. Poult enteritis-mortality syndrome. In: Diseases of poultry. 11th ed. Ames, IA: Blackwell; p. 1171-80.

125. Phan TG, Vo NP, Boros Á, Pankovics P, Reuter G, Li OTW, et al. The Viruses of Wild Pigeon Droppings. PLoS One [Internet]. 2013 Sep 4 [cited 2021 May 30];8(9). Available from: https://www.ncbi.nlm.nih.gov/pmc/artic les/PMC3762862/

126. de Souza WM, Dennis T, Fumagalli MJ, Araujo J, Sabino-Santos G, Maia FGM, et al. Novel parvoviruses from wild and domestic animals in brazil provide new insights into parvovirus distribution and diversity. Viruses. 2018;10(4):143.

127. Wang Y, Yang S, Liu D, Zhou C, Li W, Lin Y, et al. The fecal virome of redcrowned cranes. Arch Virol. 2019;164(1):3-16

128. Allander T, Tammi MT, Eriksson M, Bjerkner A, Tiveljung-Lindell A, Andersson B. Cloning of a human parvovirus by molecular screening of respiratory tract samples. Proc Natl Acad Sci USA. 2005;102(36):12891-6.

129. Sun Y, Chen AY, Cheng F, Guan W, Johnson FB, Qiu J. Molecular characterization of infectious clones of the minute virus of canines reveals unique features of bocaviruses. J Virol. 2009;83(8):3956-67.

130. Huang Q, Deng X, Yan Z, Cheng F, Luo Y, Shen W, et al. Establishment of a reverse genetics system for studying human bocavirus in human airway Epithelia. PLoS Pathog. 2012;8(8):e1002899.

131. Fasina OO, Dong Y, Pintel DJ. NP1 protein of the bocaparvovirus minute virus of canines controls access to the viral capsid genes via its role in RNA processing. J Virol. 2016;90(4):1718-28.

132. Fasina OO, Stupps S, Figueroa-Cuilan W, Pintel DJ. Minute virus of canines np1 protein governs the expression of a subset of essential nonstructural proteins via its role in RNA processing. J Virol. 2017;91(12):e00260-17.

133. Binn LN, Lazar EC, Eddy GA, Kajima M. Recovery and characterization of a minute virus of canines. Infect Immun. 1970;1 (5):503-8.

134. Carmichael LE, Schlafer DH, Hashimoto A. Minute virus of canines (MVC, canine parvovirus type-1): pathogenicity for pups and seroprevalence estimate. J Vet Diagn Invest. 1994;6(2):165-74.

135. Harrison LR, Styer EL, Pursell AR, Carmichael LE, Nietfeld JC. Fatal disease in nursing puppies associated with minute virus of canines. JVET Diagn Invest. 1992;4(1):19-22.
136. Järplid B, Johansson H, Carmichael LE. A fatal case of pup infection with minute virus of canines (MVC). J Vet Diagn Invest. 1996;8(4):484-7.

137. Carmichael LE, Schlafer DH, Hashimoto A. Pathogenicity of minute virus of canines (MVC) for the canine fetus. Cornell Vet. 1991;81(2):151-71.

138. Manteufel J, Truyen U. Animal bocaviruses: a brief review. INT. 2008;51(5):328-34

139. Decaro N, Carmichael LE, Buonavoglia C. Viral reproductive pathogens of dogs and cats. Veterinary Clinics of North America: Small Animal Practice. 2012;42(3):583-98.

140. Abinanti FR, Warfield MS. Recovery of a hemadsorbing virus (HADEN) from the gastrointestinal tract of calves. Virology. 1961;14:288-9.

141. Barnes MA, Wright RE, Bodine AB, Alberty CF. Frequency of bluetongue and bovine parvovirus infection in cattle in South Carolina dairy herds. Am J Vet Res. 1982;43(6):1078-80.

142. Uzal FA, Plattner BL, Hostetter JM. Alimentary System. In: Jubb, Kennedy \& Palmer's Pathology of Domestic Animals: Volume 2 [Internet]. Elsevier; 2016 [cited 2021 Jun 29]. p. 1-257.e2. Available from: https:// linkinghub.elsevier.com/retrieve/pii/B9780702053184000073

143. Mitra N, Cernicchiaro N, Torres S, Li F, Hause BM. Metagenomic characterization of the virome associated with bovine respiratory disease in feedlot cattle identified novel viruses and suggests an etiologic role for influenza D virus. J Gener Virol. 2016;97(8):1771-84.

144. Lau SKP, Woo PCY, Yeung HC, Teng JLL, Wu Y, Bai R, et al. Identification and characterization of bocaviruses in cats and dogs reveals a novel feline bocavirus and a novel genetic group of canine bocavirus. J Gener Virol. 2012;93(7):1573-82.

145. Ng TFF, Mesquita JR, Nascimento MSJ, Kondov NO, Wong W, Reuter G, et al. Feline fecal virome reveals novel and prevalent enteric viruses. Vet Microbiol. 2014;171(1-2):102-11.

146. Zhang W, Li L, Deng X, Kapusinszky B, Pesavento PA, Delwart E. Faecal virome of cats in an animal shelter. J Gener Virol. 2014:95(11):2553-64

147. Yi S, Niu J, Wang H, Dong G, Zhao Y, Dong H, et al. Detection and genetic characterization of feline bocavirus in Northeast China. Virol J. 2018:15(1):125.

148. Liu C, Liu F, Li Z, Qu L, Liu D. First report of feline bocavirus associated with severe enteritis of cat in Northeast China, 2015. J Vet Med Sci. 2018:80(4):731-5

149. Takano T, Takadate Y, Doki T, Hohdatsu T. Genetic characterization of feline bocavirus detected in cats in Japan. Arch Virol. 2016;161(10):2825-8

150. Piewbang C, Kasantikul T, Pringproa K, Techangamsuwan S. Feline bocavirus- 1 associated with outbreaks of hemorrhagic enteritis in household cats: potential first evidence of a pathological role, viral tropism and natural genetic recombination. Sci Rep. 2019;9(1):16367.

151. Li Y, Gordon E, Idle A, Altan E, Seguin MA, Estrada M, et al. Virome of a feline outbreak of diarrhea and vomiting includes bocaviruses and a novel chapparvovirus. Viruses. 2020;12(5).

152. Kapoor A, Mehta N, Dubovi EJ, Simmonds P, Govindasamy L, Medina JL, et al. Characterization of novel canine bocaviruses and their association with respiratory disease. J Gener Virol. 2012;93(2):341-6.

153. Bodewes R, Lapp S, Hahn K, Habierski A, Förster C, König M, et al. Novel canine bocavirus strain associated with severe enteritis in a dog litter. Vet Microbiol. 2014;174(1-2):1-8.

154. Piewbang C, Jo WK, Puff C, Ludlow M, van der Vries E, Banlunara W, et al. Canine bocavirus Type 2 infection associated with intestinal Lesions. Vet Pathol. 2018;55(3):434-41.

155. Li L, Pesavento PA, Leutenegger CM, Estrada M, Coffey LL, Naccache SN, et al. A novel bocavirus in canine liver. Virol J. 2013;10(1):54.

156. Blomström A-L, Belák S, Fossum C, McKillen J, Allan G, Wallgren P, et al. Detection of a novel porcine boca-like virus in the background of porcine circovirus type 2 induced postweaning multisystemic wasting syndrome. Virus Res. 2009;146(1-2):125-9.

157. Aryal M, Liu G. Porcine Bocavirus: a 10-year history since its discovery. Virol Sin. 2021;

158. Blomström A-L, Belák S, Fossum C, Fuxler L, Wallgren P, Berg M. Studies of porcine circovirus type 2, porcine boca-like virus and torque teno virus indicate the presence of multiple viral infections in postweaning multisystemic wasting syndrome pigs. Virus Res. 2010;152(1-2):59-64. 
159. Shan T, Lan D, Li L, Wang C, Cui L, Zhang W, et al. Genomic characterization and high prevalence of bocaviruses in swine. PLOS ONE. 2011;6(4):e17292.

160. Zhai S, Yue C, Wei Z, Long J, Ran D, Lin T, et al. High prevalence of a novel porcine bocavirus in weanling piglets with respiratory tract symptoms in China. Arch Virol. 2010;155(8):1313-7.

161. Wu Z, Ren X, Yang L, Hu Y, Yang J, He G, et al. Virome analysis for identification of novel mammalian viruses in bat species from Chinese Provinces. J Virol. 2012;86(20):10999-1012.

162. He B, Li Z, Yang F, Zheng J, Feng Y, Guo H, et al. Virome profiling of bats from myanmar by metagenomic analysis of tissue samples reveals more novel mammalian viruses. PLoS ONE. 2013:8(4):e61950.

163. Lau SKP, Ahmed SS, Yeung HC, Li KSM, Fan RYY, Cheng TYC, et al. Identification and interspecies transmission of a novel bocaparvovirus among different bat species in China. J Gener Virol. 2016;97(12):3345-58.

164. Lau SKP, Yeung HC, Li KSM, Lam CSF, Cai J-P, Yuen M-C, et al. Identification and genomic characterization of a novel rat bocavirus from brown rats in China. Infect Genet Evol. 2017:47:68-76.

165. Woo PCY, Lau SKP, Tsoi H-W, Patteril NG, Yeung HC, Joseph S, et al. Two novel dromedary camel bocaparvoviruses from dromedaries in the Middle East with unique genomic features. J Gener Virol. 2017;98(6):1349-59.

166. Xiong Y-Q, Zhou J-H, Zhang M-Y, You F-F, Li D-L, Chen Q. Presence of rat bocavirus in oropharyngeal and fecal samples from murine rodents in China. Arch Virol. 2018;163(11):3099-103.

167. Yang S, Wang Y, Li W, Fan Z, Jiang L, Lin Y, et al. A novel bocavirus from domestic mink. China Virus Genes. 2016;52(6):887-90.

168. Lanave G, Martella V, Farkas SL, Marton S, Fehér E, Bodnar L, et al. Novel bocaparvoviruses in rabbits. Vet J. 2015;206(2):131-5.

169. Li L, Shan T, Wang C, Cote C, Kolman J, Onions D, et al. The fecal viral flora of california sea lions. J Virol. 2011;85(19):9909-17.

170. Cheung AK, Wu G, Wang D, Bayles DO, Lager KM, Vincent AL. Identification and molecular cloning of a novel porcine parvovirus. Arch Virol. 2010;155(5):801-6.

171. Theiler A. Acute Liver-Atrophy and Parenchymatous Hepatitis in Horses. Acute Liver-Atrophy and Parenchymatous Hepatitis in Horses [Internet]. 1918 [cited 2019 Sep 10]; Available from: https://www.cabdirect.org/ cabdirect/abstract/19206300041

172. Tomlinson JE, Tennant BC, Struzyna A, Mrad D, Browne N, Whelchel $D$, et al. Viral testing of 10 cases of Theiler's disease and 37 in-contact horses in the absence of equine biologic product administration: A prospective study (2014-2018). J Vet Intern Med. 2019;33(1):258-65.

173. Tomlinson JE, Kapoor A, Kumar A, Tennant BC, Laverack MA, Beard L, et al. Viral testing of 18 consecutive cases of equine serum hepatitis: A prospective study (2014-2018). J Vet Intern Med. 2019;33(1):251-7.

174. Lu G, Wu L, Ou J, Li S. Equine Parvovirus-Hepatitis in China: Characterization of Its Genetic Diversity and Evidence for Natural Recombination Events Between the Chinese and American Strains. Front Vet Sci [Internet]. 2020 [cited 2020];7. Available from: https://www.ncbi.nlm.nih.gov/ pmc/articles/PMC7076910/

175. Badenhorst M, de Heus P, Auer A, Tegtmeyer B, Stang A, Dimmel K, et al. Active equine parvovirus-hepatitis infection is most frequently detected in Austrian horses of advanced age. Equine Vet J. 2021;

176. Meister TL, Tegtmeyer B, Postel A, Cavalleri J-MV, Todt D, Stang A, et al. Equine Parvovirus-Hepatitis Frequently Detectable in Commercial Equine Serum Pools. Viruses [Internet]. 2019 May 21 [cited 2019 Jun 25];11(5). Available from: https://www.ncbi.nlm.nih.gov/pmc/articles/ PMC6563276/

177. Mann S, Ramsay JD, Wakshlag JJ, Stokol T, Reed S, Divers TJ. Investigating the pathogenesis of high-serum gamma-glutamyl transferase activity in Thoroughbred racehorses: A series of case-control studies. Equine Vet J. 2021;evj.13435.

178. Altan E, Li Y, Sabino-Santos G Jr, Sawaswong V, Barnum S, Pusterla N, et al. Viruses in horses with neurologic and respiratory diseases. Viruses. 2019;11(10):942.

179. Baird J, Tegtmeyer B, Arroyo L, Stang A, Brüggemann Y, Hazlett M, et al. The association of Equine Parvovirus-Hepatitis (EqPV-H) with cases of non-biologic-associated Theiler's disease on a farm in Ontario, Canada. Vet Microbiol. 2020:242:108575.

180. Allander T, Emerson SU, Engle RE, Purcell RH, Bukh J. A virus discovery method incorporating DNase treatment and its application to the identification of two bovine parvovirus species. Proc Natl Acad Sci. 2001;98(20):11609-14.

181. Sadeghi M, Kapusinszky B, Yugo DM, Phan TG, Deng X, Kanevsky I, et al. Virome of US bovine calf serum. Biologicals. 2017;46:64-7.

182. Zhang M, Hill JE, Godson DL, Ngeleka M, Fernando C, Huang Y. The pulmonary virome, bacteriological and histopathological findings in bovine respiratory disease from western Canada. Transbound Emerg Dis. 2020;67(2):924-34.

183. Baylis SA, Miskey C, Blümel J, Kaiser M, Kapusinszky B, Delwart E. Identification of a novel bovine copiparvovirus in pooled fetal bovine serum. Virus Genes [Internet]. 2020 [cited 2020 May 15]https://doi.org/10. 1007/s11262-020-01757-1

184. Huang L, Zhai S-L, Cheung AK, Zhang H-B, Long J-X, Yuan S-S. Detection of a novel porcine parvovirus, PPV4, in chinese swine herds. Virol J. 2010;21(7):333

185. Xiao C-T, Giménez-Lirola LG, Halbur PG, Opriessnig T. Increasing porcine PARV4 prevalence with pig age in the US pig population. Vet Microbiol. 2012;160(3-4):290-6.

186. Opriessnig T, Xiao C-T, Gerber PF, Halbur PG. Identification of recently described porcine parvoviruses in archived North American samples from 1996 and association with porcine circovirus associated disease. Vet Microbiol. 2014;173(1-2):9-16.

187. Cadar D, Lőrincz M, Kiss T, Novosel D, Podgorska K, Becskei Z, et al. Emerging novel porcine parvoviruses in Europe: origin, evolution, phylodynamics and phylogeography. J Gen Virol. 2013;94(Pt 10):2330-7.

188. Cui J, Fan J, Gerber PF, Biernacka K, Stadejek T, Xiao C-T, et al. First identification of porcine parvovirus 6 in Poland. Virus Genes. 2017;53(1):100-4

189. Afolabi KO, Iweriebor BC, Okoh Al, Obi LC. Increasing diversity of swine parvoviruses and their epidemiology in African pigs. Infect Genet Evol. 2019:73:175-83.

190. Ndze VN, Cadar D, Cságola A, Kisfali P, Kovács E, Farkas S, et al. Detection of novel porcine bocaviruses in fecal samples of asymptomatic pigs in Cameroon. Infect Genet Evol. 2013;17:277-82.

191. Thuy NTD, Trung NT, Dung TQ, Khoa DVA, Thuy DTN, Opriessnig T. First investigation of the prevalence of parvoviruses in slaughterhouse pigs and genomic characterization of ungulate copiparvovirus 2 in Vietnam. Arch Virol. 2021;166(3):779-88.

192. Blomström A-L, Ståhl K, Masembe C, Okoth E, Okurut AR, Atmnedi P, et al. Viral metagenomic analysis of bushpigs (Potamochoerus larvatus) in Uganda identifies novel variants of Porcine parvovirus 4 and Torque teno sus virus 1 and 2. Virology Journal. 2012;9(1):192.

193. Park G-N, Song S, Cha RM, Choe S, Shin J, Kim S-Y, et al. Genetic Analysis of Porcine Parvoviruses Detected in South Korean Wild Boars [Internet]. In Review; 2021 [cited 2021 May 31]. Available from: https://www.resea rchsquare.com/article/rs-344017/v1

194. Ni J, Qiao C, Han X, Han T, Kang W, Zi Z, et al. Identification and genomic characterization of a novel porcine parvovirus (PPV6) in China. Virol J. 2014;11:203.

195. Schirtzinger EE, Suddith AW, Hause BM, Hesse RA. First identification of porcine parvovirus 6 in North America by viral metagenomic sequencing of serum from pigs infected with porcine reproductive and respiratory syndrome virus. Virol J. 2015;12:170.

196. Giannitti F, Ullmann LS, Deng X, Pesavento PA, Delwart E, Pusterla $\mathrm{N}$, et al. Exploring the virome of diseased horses. J Gener Virol. 2015;96(9):2721-33.

197. Xie J, Tong P, Zhang A, Song X, Zhang L, Shaya N, et al. An emerging equine parvovirus circulates in thoroughbred horses in north Xinjiang, China, 2018. Transbound Emerg Dis. 2020;67(3):1052-6.

198. Linden A, Gilliaux G, Paternostre J, Benzarti E, Rivas JF, Desmecht D, et al A novel parvovirus, Roe deer copiparvovirus, identified in Ixodes ricinus ticks. Virus Genes. 2019;55(3):425-8.

199. Phan TG, Gulland F, Simeone C, Deng X, Delwart E. Sesavirus: prototype of a new parvovirus genus in feces of a sea lion. Virus Genes. 2015;50(1):134-6.

200. Mosena ACS, da Silva MS, Lorenzett MP, Cibulski SP, Weber MN Budaszewski RF, et al. A new highly divergent copiparvovirus in sheep. Arch Virol. 2021;166(5):1517-20.

201. Palya V. Parvovirus infections of waterfowl. In: Diseases of poultry. 13th ed. Ames, IA: Wiley-Blackwell; p. 444-51. 
202. Atchison RW, Casto BC, Hammon WM. Adenovirus-associated defective virus particles. Science. 1965;149(3685):754-6.

203. Hoggan MD, Blacklow NR, Rowe WP. Studies of small DNA viruses found in various adenovirus preparations: physical, biological, and immunological characteristics. Proc Natl Acad Sci USA. 1966;55(6):1467-74.

204. Fang D. Recommendation of gosling plague. China Anim Husband Vet Med. 1962:8:19-20.

205. Derzsy D. A viral disease of goslings I Epidemiological, clinical, pathological and aetiological studies. Acta Vet Acad Sci Hung. 1967;17(4):443-8.

206. Fang D, Wang Y, Zheng Y, Zhou Y, Jiang M, Dong G. Studies on the aetiology and specific control of gosling plague. Sci Agric Sin. 1981;4:1-8.

207. Zádori Z, Stefancsik R, Rauch T, Kisary J. Analysis of the complete nucleotide sequences of goose and muscovy duck parvoviruses indicates common ancestral origin with adeno-associated virus 2. Virology. 1995;212(2):562-73.

208. Wang J, Mi Q, Wang Z, Jia J, Li Y, Zhu G. Sole recombinant Muscovy duck parvovirus infection in Muscovy ducklings can form characteristic intestinal embolism. Vet Microbiol. 2020;242:108590.

209. Wu G, Shi J, Yu Y. Differential diagnosis and immunization prevention of two parvoviral diseases in Muscovy ducks. Anim Husb Vet Med. 28(6):264.

210. Li P, Lin S, Zhang R, Chen J, Sun D, Lan J, et al. Isolation and characterization of novel goose parvovirus-related virus reveal the evolution of waterfowl parvovirus. Transbound Emerg Dis. 2018;65(2):e284-95.

211. Chen $H$, Tang $Y$, Dou Y, Zheng $X$, Diao $Y$. Evidence for vertical transmission of novel duck-origin goose parvovirus-related parvovirus. Transbound Emerg Dis. 2016;63(3):243-7.

212. Yu K, Ma X, Sheng Z, Qi L, Liu C, Wang D, et al. Identification of Goose-origin parvovirus as a cause of newly emerging beak atrophy and dwarfism syndrome in ducklings. J Clin Microbiol. 2016;54(8):1999-2007.

213. Matczuk AK, Chmielewska-Władyka M, Siedlecka M, Bednarek KJ, Wieliczko A. Short beak and dwarfism syndrome in ducks in poland caused by novel goose parvovirus. Animals. 2020;10(12):2397.

214. Soliman MA, Erfan AM, Samy M, Mahana O, Nasef SA. Detection of novel goose parvovirus disease associated with short beak and dwarfism syndrome in commercial ducks. Animals (Basel). 2020;10(10):1833.

215. Yates VJ, El Mishad AM, McCormick KJ, Trentin JJ. Isolation and characterization of an avian adenovirus-associated virus. Infect Immun. 1973;7(6):973-80

216. Bossis I, Chiorini JA. Cloning of an avian adeno-associated virus (AAAV) and generation of recombinant AAAV particles. J Virol. 2003;77(12):6799-810.

217. Waldner DM, Visser F, Fischer AJ, Bech-Hansen NT, Stell WK. Avian Adeno-Associated Viral Transduction of the Postembryonic Chicken Retina. Trans Vis Sci Tech. 2019;8(4):1-1.

218. Wang AP, Liu L, Gu LL, Guo CM, Wu S, Feng Q, et al. Protection against duck hepatitis a virus type 1 conferred by a recombinant avian adenoassociated virus. Poult Sci. 2019;98(1):112-8.

219. Li Y, Ge X, Hon C-C, Zhang H, Zhou P, Zhang Y, et al. Prevalence and genetic diversity of adeno-associated viruses in bats from China. J Gener Virol. 2010:91(10):2601-9.

220. Zhu C, Wang C, Wu J, Ye F, Lv R, Hu D, et al. Distribution and genetic diversity of adeno-associated viruses in bats from coastal areas of Southeast China. Sci Rep. 2020;10(1):3725.

221. Mietzsch M, Li Y, Kurian J, Smith JK, Chipman P, McKenna R, et al. Structural characterization of a bat Adeno-associated virus capsid. J Struct Biol. 2020;211(2):1075

222. Li Y, Li J, Liu Y, Shi Z, Liu H, Wei Y, et al. Bat adeno-associated viruses as gene therapy vectors with the potential to evade human neutralizing antibodies. Gene Ther. 2019;26(6):264-76.

223. Williams SH, Che X, Garcia JA, Klena JD, Lee B, Muller D, et al. Viral diversity of house mice in New York City. mBio. 2018 May 2 [cited 2021 Jun 9];9(2). https://doi.org/10.1128/mBio.01354-17

224. Farkas SL, Zádori Z, Benkő M, Essbauer S, Harrach B, Tijssen P. A parvovirus isolated from royal python (Python regius) is a member of the genus Dependovirus. J Gener Virol. 2004;85(3):555-61.

225. Farkas S, Gal J. First Hungarian report of inclusion body hepatitis associated with adenovirus and secondary parvovirus infection in an
Indonesian pit viper (Parias (Trimeresurus) hageni). Magy Allatorvosok. 2008;130:755-61.

226. Pénzes JJ, Benkő M. Novel parvovirus from the worm lizard Trogonophis wiegmanni-first virus ever detected in amphisbaenian hosts. Acta Vet Hung. 2014;62(2):284-92.

227. Pénzes JJ, Pham HT, Benkö M, Tijssen P. Novel parvoviruses in reptiles and genome sequence of a lizard parvovirus shed light on Dependoparvovirus genus evolution. J Gener Virol. 2015;96(9):2769-79.

228. Broliden $\mathrm{K}$, Tolfvenstam $\mathrm{T}$, Norbeck $\mathrm{O}$. Clinical aspects of parvovirus B19 infection. J Intern Med. 2006;260(4):285-304.

229. Bonvicini F, Puccetti C, Salfi NCM, Guerra B, Gallinella G, Rizzo N, et al. Gestational and fetal outcomes in B19 maternal infection: a problem of diagnosis. J Clin Microbiol. 2011;49(10):3514-8.

230. Heegaard ED, Qvortrup K, Christensen J. Baculovirus expression of erythrovirus V9 capsids and screening by ELISA: serologic crossreactivity with erythrovirus B19. J Med Virol. 2002;66(2):246-52.

231. Chaves A, Ibarra-Cerdeña CN, López-Pérez AM, Monge O, Avendaño $\mathrm{R}$, Ureña-Saborio $\mathrm{H}$, et al. Bocaparvovirus, erythroparvovirus and tetraparvovirus in new world primates from Central America. Transbound Emerg Dis. 2020:67(1):377-87.

232. Green SW, Malkovska I, O'Sullivan MG, Brown KE. Rhesus and pigtailed macaque parvoviruses: identification of two new members of the erythrovirus genus in monkeys. Virology. 2000;269(1):105-12.

233. Yoo BC, Lee DH, Park SM, Park JW, Kim CY, Lee HS, et al. A novel parvovirus isolated from Manchurian chipmunks. Virology. 1999;253(2):250-8.

234. Chen Z, Chen AY, Cheng F, Qiu J. Chipmunk parvovirus is distinct from members in the genus erythrovirus of the family parvoviridae. PLOS ONE. 2010;5(12):e15113.

235. Bodewes R, García AR, Wiersma LCM, Getu S, Beukers M, Schapendonk CME, et al. Novel B19-like parvovirus in the brain of a harbor seal. PLoS ONE. 2013;8(11):e79259.

236. Bodewes R, Hapsari R, Rubio García A, Sánchez Contreras GJ, van de Bildt MWG, de Graaf M, et al. Molecular epidemiology of seal parvovirus, 1988-2014. PLoS ONE [Internet]. 2014 Nov 12 [cited 2021];9(11).

237. Canuti M, Williams CV, Gadi SR, Jebbink MF, Oude Munnink BB, Jazaer Farsani SM, et al. Persistent viremia by a novel parvovirus in a slow loris (Nycticebus coucang) with diffuse histiocytic sarcoma. Front Microbiol. 2014;5:655.

238. Chang YC, Lin ZY, Lin YX, Lin KH, Chan FT, Hsiao ST, et al. Canine Parvovirus Infections in Taiwanese Pangolins (Manis pentadactyla pentadactyla). Vet Pathol. 2021;03009858211002198.

239. Wang S, Tu Y, Lee M, Wu L, Chen T, Wu C, et al. Fatal canine parvovirus-2 (CPV-2) infection in a rescued free-ranging Taiwanese pangolin (Manis pentadactyla pentadactyla). Transbound Emerg Dis. 2020;67(3):1074-81.

240. Holzworth J. Diseases of the cat. In Philadelphia: WB Saunders; 1987. p. 182-93.

241. Johnson R. Isolation of a virus from a condition simulating feline panleucopaenia in a leopard. Vet Record. 1964;

242. Gorham JR, Hartsough GR, Burger D, Lust S, Sato N. The preliminary use of attenuated feline panleukopenia virus to protect cats against panleukopenia and mink against virus enteritis. Cornell Vet. 1965:55(4):559-66.

243. Stone AE, Brummet GO, Carozza EM, Kass PH, Petersen EP, Sykes J, et al. 2020 AAHA/AAFP feline vaccination quidelines. J Feline Med Surg. 2020;22(9):813-30.

244. Csiza CK, Scott FW, De Lahunta A, Gillespie JH. Pathogenesis of feline panleukopenia virus in susceptible newborn Kittens I. Clinical signs, hematology, serology, and virology. Infect Immun. 1971;3(6):833-7.

245. Agbandje M, McKenna R, Rossmann MG, Strassheim ML, Parrish CR. Structure determination of feline panleukopenia virus empty particles. Proteins. 1993;16(2):155-71.

246. Songaksorn N, Petsophonsakul W, Pringproa K, Lampang KN, Sthitmatee N, Srifawattana N, et al. Prevalence of autoantibodies that bind to kidney tissues in cats and association risk with antibodies to feline viral rhinotracheitis, calicivirus, and panleukopenia. J Vet Sci. 2021;22(3):e38.

247. Leal É, Liang R, Liu Q, Villanova F, Shi L, Liang L, et al. Regional adaptations and parallel mutations in Feline panleukopenia virus strains from China revealed by nearly-full length genome analysis. PLOS ONE. 2020;15(1):e0227705. 
248. Ndiana LA, Lanave G, Desario C, Berjaoui S, Alfano F, Puglia I, et al. Circulation of diverse protoparvoviruses in wild carnivores, Italy. Transbound Emerg Dis. 2020

249. Chung H-C, Kim S-J, Nguyen VG, Shin S, Kim JY, Lim S-K, et al. New genotype classification and molecular characterization of canine and feline parvoviruses. J Vet Sci. 2020;21(3):e43.

250. Chaiyasak S, Piewbang C, Banlunara W, Techangamsuwan S. Carnivore protoparvovirus-1 associated with an outbreak of hemorrhagic gastroenteritis in small Indian Civets. Vet Pathol. 2020;57(5):706-13.

251. Van Brussel K, Carrai M, Lin C, Kelman M, Setyo L, Aberdein D, et al. Distinct lineages of feline parvovirus associated with epizootic outbreaks in Australia, New Zealand and the United Arab Emirates. Viruses. 2019;11(12):1155

252. Truyen U, Gruenberg A, Chang SF, Obermaier B, Veijalainen P, Parrish CR. Evolution of the feline-subgroup parvoviruses and the control of canine host range in vivo. J Virol. 1995;69(8):4702-10.

253. Chang SF, Sgro JY, Parrish CR. Multiple amino acids in the capsid structure of canine parvovirus coordinately determine the canine host range and specific antigenic and hemagglutination properties. J Virol. 1992:66(12):6858-67.

254. Shackelton LA, Parrish CR, Truyen U, Holmes EC. High rate of viral evolution associated with the emergence of carnivore parvovirus. Proc Natl Acad Sci USA. 2005;102(2):379-84

255. Carman PS, Povey RC. Pathogenesis of canine parvovirus-2 in dogs: haematology, serology and virus recovery. Res Vet Sci. 1985;38(2):134-40.

256. Hoelzer K, Shackelton LA, Holmes EC, Parrish CR. Within-host genetic diversity of endemic and emerging parvoviruses of dogs and cats. J Virol. 2008;82(22):11096-105.

257. Meunier PC, Cooper BJ, Appel MJ, Slauson DO. Experimental viral myocarditis: parvoviral infection of neonatal pups. Vet Pathol. 1984;21(5):509-15.

258. Sime TA, Powell LL, Schildt JC, Olson EJ. Parvoviral myocarditis in a 5-week-old Dachshund. J Vet Emerg Crit Care (San Antonio). 2015;25(6):765-9.

259. Kelly WR. An enteric disease of dogs reselmbing feline panleucopaenia. Aust Vet J. 1978;54(12):593.

260. Appel MJ, Scott FW, Carmichael LE. Isolation and immunisation studies of a canine parco-like virus from dogs with haemorrhagic enteritis. Vet Rec. 1979;105(8):156-9.

261. Carmichael LE, Joubert JC, Pollock RV. A modified live canine parvovirus vaccine. II. Immune Response Cornell Vet. 1983;73(1):13-29.

262. Sagazio P, Tempesta M, Buonavoglia D, De Palma M, Buonavoglia C. Antigenic relationship between CPV2 and CPV2b: results of a serological study. In Utrecht, The Netherlands; 1998. p. 43.

263. Appel M, Carmichael L. Can a commercial vaccine protect pups against a recent isolate of canine parvovirus? Vet Med. 1987;10:1091-3.

264. Voorhees IEH, Lee H, Allison AB, Lopez-Astacio R, Goodman LB, Oyesola $\mathrm{OO}$, et al. Limited intrahost diversity and background evolution accompany 40 Years of Canine parvovirus host adaptation and spread. J Virol. 2019;94(1):e01162-e1219.

265. Hafenstein S, Bowman VD, Sun T, Nelson CDS, Palermo LM, Chipman $\mathrm{PR}$, et al. Structural comparison of different antibodies interacting with parvovirus capsids. J Virol. 2009:83(11):5556-66.

266. Organtini LJ, Lee H, Iketani S, Huang K, Ashley RE, Makhov AM, et al. Near-atomic resolution structure of a highly neutralizing fab bound to canine parvovirus. J Virol. 2016;90(21):9733-42.

267. Allison AB, Kohler DJ, Ortega A, Hoover EA, Grove DM, Holmes EC, et al. Host-specific parvovirus evolution in nature is recapitulated by in vitro adaptation to different carnivore species. PLoS Pathog. 2014;10(11):e1004475

268. Mayr A, Mahnel H. Cultivation of hog cholera virus in pig kidney cultures with cytopathogenic effect. Zentralbl Bakteriol Orig. 1964;195(2):157-66

269. Cartwright H. Vet Rec. 1967:81:196.

270. Mészáros I, Olasz F, Cságola A, Tijssen P, Zádori Z. Biology of porcine parvovirus (Ungulate parvovirus 1). Viruses. 2017:9(12).

271. Streck AF, Truyen U. Porcine parvovirus. Curr Issues Mol Biol. 2020;33-46.

272. Crawford LV. A minute virus of mice. Virology. 1966;29(4):605-12.

273. Kilham L, Margolis G. Pathogenicity of Minute Virus of Mice (MVM) for rats, mice, and hamsters. Exp Biol Med. 1970;133(4):1447-52.
274. Singleton GR, Smith AL, Shellam GR, Fitzgerald N, Müller WJ. Prevalence of viral antibodies and helminths in field populations of house mice (Mus domesticus) in southeastern Australia. Epidemiol Infect. 1993;110(2):399-417

275. Engers HD, Louis JA, Zubler RH, Hirt B. Inhibition of T cell-mediated functions by MVM(i), a parvovirus closely related to minute virus of mice. J Immunol. 1981;127(6):2280-5.

276. Brownstein DG, Smith AL, Johnson EA, Pintel DJ, Naeger LK, Tattersall P. The pathogenesis of infection with minute virus of mice depends on expression of the small nonstructural protein NS2 and on the genotype of the allotropic determinants VP1 and VP2. J Virol. 1992;66(5):3118-24.

277. Jacoby RO, Ball-Goodrich LJ, Besselsen DG, McKisic MD, Riley LK, Smith AL. Rodent parvovirus infections. Lab Anim Sci. 1996;46(4):370-80.

278. Kimsey PB, Engers HD, Hirt B, Jongeneel CV. Pathogenicity of fibroblastand lymphocyte-specific variants of minute virus of mice. J Virol. 1986:59(1):8-13.

279. Majumder K, Boftsi M, Whittle FB, Wang J, Fuller MS, Joshi T, et al. The NS1 protein of the parvovirus MVM Aids in the localization of the viral genome to cellular sites of DNA damage. PLoS Pathog. 2020:16(10):e1009002.

280. Kilham L, Olivier LJ. A latent virus of rats isolated in tissue culture. Virology. 1959;7(4):428-37

281. Toolan HW, Dalldore G, Barclay M, Chandra S, Moore AE. An unidentified, filtrable agent isolated from transplanted human tumors. Proc Natl Acad Sci. 1960:46(9):1256-8

282. Ball-Goodrich LJ, Leland SE, Johnson EA, Paturzo FX, Jacoby RO. Rat parvovirus type 1: the prototype for a new rodent parvovirus serogroup. J Virol. 1998;72(4):3289-99.

283. Wan C-H, Söderlund-Venermo M, Pintel DJ, Riley LK. Molecular characterization of three newly recognized rat parvoviruses. J Gener Virol. 2002:83(8):2075-83.

284. Coleman GL, Jacoby RO, Bhatt PN, Smith AL, Jonas AM. Naturally occurring lethal parvovirus infection of juvenile and young-adult rats. Vet Pathol. 1983;20(1):49-56.

285. Siqueira JD, Ng TF, Miller M, Li L, Deng X, Dodd E, et al. Endemic infection of stranded southern sea otters (Enhydra lutris nereis) with novel parvovirus, polyomavirus, and adenovirus. J Wildl Dis. 2017:53(3):532-42.

286. Martella V, Lanave G, Mihalov-Kovács E, Marton S, Varga-Kugler R, Kaszab E, et al. Novel Parvovirus Related to Primate Bufaviruses in Dogs. Emerg Infect Dis. 2018;24(6):1061-8.

287. Shao R, Zheng F, Cai S, Ji J, Ren Z, Zhao J, et al. Genomic sequencing and characterization of a novel group of canine bufaviruses from Henan province. China Arch Virol. 2020;165(11):2699-702.

288. Li J, Cui L, Deng X, Yu X, Zhang Z, Yang Z, et al. Canine bufavirus in faeces and plasma of dogs with diarrhoea. China Emerg Microb Infect. 2019;8(1):245-7.

289. Di Martino B, Sarchese V, Di Profio F, Palombieri A, Melegari I, Fruci P, et al. Genetic heterogeneity of canine bufaviruses. Transbound Emerg Dis. 2021;68(2):802-12.

290. Melegari I, Di Profio F, Palombieri A, Sarchese V, Diakoudi G, Robetto $\mathrm{S}$, et al. Molecular detection of canine bufaviruses in wild canids. Arch Virol. 2019:164(9):2315-20.

291. Diakoudi G, Lanave G, Capozza P, Di Profio F, Melegari I, Di Martino B, et al. Identification of a novel parvovirus in domestic cats. Vet Microbiol. 2019;228:246-51

292. Bodewes R, van der Giessen J, Haagmans BL, Osterhaus ADME, Smits SL. Identification of multiple novel viruses, including a parvovirus and a hepevirus, in feces of red foxes. J Virol. 2013;87(13):7758-64.

293. Lojkić I, Biđin M, Prpić J, Šimić I, Krešić N, Bedeković T. Faecal virome of red foxes from peri-urban areas. Comp Immunol Microbiol Infect Dis. 2016:45:10-5

294. Hargitai R, Pankovics P, Kertész AM, Bíró H, Boros Á, Phan TG, et al. Detection and genetic characterization of a novel parvovirus distantly related to human bufavirus in domestic pigs. Arch Virol. 2016:161(4):1033-7.

295. Huang H, Li Y, Wang W, Zheng M, Cao L, Sun W, et al. Detection and molecular characterization of novel porcine bufaviruses in Guangxi province. Infect Genet Evol. 2020;82:104286 
296. Zhou L, Hu C, Zhou Q, Yang D, Wang L, Zhang B. Viral communities associated with porcine diarrhoeal disease and genetic characterization of a bufavirus in Tibetan pigs in China. Arch Virol. 2021;166(2):613-7.

297. Paim WP, Maggioli MF, Weber MN, Rezabek G, Narayanan S, Ramachandran A, et al. Virome characterization in serum of healthy show pigs raised in Oklahoma demonstrated great diversity of ssDNA viruses. Virology. 2021;556:87-95.

298. Liu L, Schwarz L, Ullman K, Ahola H, Qiu Y, Ma Z, et al. Identification of a novel bufavirus in domestic pigs by a viral metagenomic approach. J Gener Virol. 2016;97(7):1592-6.

299. Altan E, Delaney MA, Colegrove KM, Spraker TR, Wheeler EA, Deng X, et al. Complex Virome in a Mesenteric Lymph Node from a Californian Sea Lion (Zalophus californianus) with Polyserositis and Steatitis. Viruses. 2020;12(8).

300. Jones MS, Kapoor A, Lukashov VV, Simmonds P, Hecht F, Delwart E. New DNA viruses identified in patients with acute viral infection syndrome. J Virol. 2005;79(13):8230-6.

301. Hijikata M, Abe K, Win KM, Shimizu YK, Keicho N, Yoshikura H. Identification of new parvovirus DNA sequence in swine sera from Myanmar. Jpn J Infect Dis. 2001;54(6):244-5.

302. Wang F, Wei Y, Zhu C, Huang X, Xu Y, Yu L, et al. Novel parvovirus sublineage in the family of Parvoviridae. Virus Genes. 2010;41(2):305-8.

303. Cságola A, Lőrincz M, Cadar D, Tombácz K, Biksi I, Tuboly T. Detection, prevalence and analysis of emerging porcine parvovirus infections. Arch Virol. 2012;157(6):1003-10.

304. Xiao C-T, Gerber PF, Giménez-Lirola LG, Halbur PG, Opriessnig T. Characterization of porcine parvovirus type 2 (PPV2) which is highly prevalent in the USA. Vet Microbiol. 2013;161(3-4):325-30.

305. Streck AF, Homeier T, Foerster T, Fischer S, Truyen U. Analysis of porcine parvoviruses in tonsils and hearts from healthy pigs reveals high prevalence and genetic diversity in Germany. Arch Virol. 2013;158(6):1173-80

306. Novosel D, Cadar D, Tuboly T, Jungic A, Stadejek T, Ait-Ali T, et al. Investigating porcine parvoviruses genogroup 2 infection using in situ polymerase chain reaction. BMC Vet Res [Internet]. 2018 May 21 [cited 2021 Jun 2];14.

307. Saekhow P, Mawatari T, Ikeda H. Coexistence of multiple strains of porcine parvovirus 2 in pig farms. Microbiol Immunol. 2014;58(7):382-7.

308. Lau SKP, Woo PCY, Tse H, Fu CTY, Au W-K, Chen X-C, et al. Identification of novel porcine and bovine parvoviruses closely related to human parvovirus 4.J Gener Virol. 2008:89(8):1840-8.

309. Xu F, Pan Y, Wang M, Wu X, Tian L, Baloch AR, et al. First detection of ungulate tetraparvovirus 1 (bovine hokovirus 1) in domestic yaks in northwestern China. Arch Virol. 2016;161(1):177-80.

310. Adlhoch C, Kaiser M, Kingsley MT, Schwarz NG, Ulrich M, de Paula VS, et al. Porcine hokovirus in domestic pigs. Cameroon Emerg Infect Dis. 2013;19(12):2060-2.

311. Tse H, Tsoi H-W, Teng JLL, Chen X-C, Liu H, Zhou B, et al. Discovery and genomic characterization of a novel ovine partetravirus and a new genotype of bovine partetravirus. PLoS ONE. 2011;6(9):e25619.

312. Parrish CR. Exposing a virus hiding in the animal facility. Cell. 2018:175(2):310-1.

313. Barthold B, Percy D, Griffey S. Pathology of laboratory rodents and rabbits. 4th ed. New York: Wiley; 2016

314. Yamkasem J, Tattiyapong P, Gorgoglione B, Surachetpong W. Uncovering the first occurrence of Tilapia parvovirus in Thailand in tilapia during co-infection with Tilapia tilapinevirus. Transbound Emerg Dis. 2021;tbed.14143.

315. Palinski RM, Mitra N, Hause BM. Discovery of a novel Parvovirinae virus, porcine parvovirus 7 , by metagenomic sequencing of porcine rectal swabs. Virus Genes. 2016;52(4):564-7.

316. Xing $X$, Zhou H, Tong L, Chen Y, Sun Y, Wang H, et al. First identification of porcine parvovirus 7 in China. Arch Virol. 2018;163(1):209-13.

317. Miłek D, Woźniak A, Stadejek T. The detection and genetic diversity of novel porcine parvovirus 7 (PPV7) on Polish pig farms. Res Vet Sci. 2018;120:28-32

318. Da Silva MS, Budaszewski RF, Weber MN, Cibulski SP, Paim WP, Mósena ACS, et al. Liver virome of healthy pigs reveals diverse small ssDNA viral genomes. Infect Genet Evol. 2020;81:104203.
319. Blomström A-L, Ye X, Fossum C, Wallgren P, Berg M. Characterisation of the virome of tonsils from conventional pigs and from specific pathogen-free pigs. Viruses. 2018;10(7):382.

320. Ouh I-O, Park S, Lee J-Y, Song JY, Cho I-S, Kim H-R, et al. First detection and genetic characterization of porcine parvovirus 7 from Korean domestic pig farms. J Vet Sci. 2018;19(6):855.

321. Wang D, Mai J, Yang Y, Wang N. Porcine Parvovirus 7: evolutionary dynamics and identification of epitopes toward vaccine design. Vaccines (Basel). 2020:8(3):359.

322. Fahsbender E, Altan E, Seguin MA, Young P, Estrada M, Leutenegger C, et al. Chapparvovirus DNA found in $4 \%$ of dogs with diarrhea. Viruses. 2019:11(5):398.

323. Hu W, Liu Q, Chen Q, Ji J. Molecular characterization of Cachavirus firstly detected in dogs in China. Infect Genet Evol. 2020:85:104529.

324. Palombieri A, Di Profio F, Lanave G, Capozza P, Marsilio F, Martella V, et al. Molecular detection and characterization of Carnivore chaphamaparvovirus 1 in dogs. Vet Microbiol. 2020;251:108878.

325. Ji J, Hu W, Liu Q, Zuo K, Zhi G, Xu X, et al. genetic analysis of cachavirusrelated parvoviruses detected in pet cats: the first report from China. Front Vet Sci. 2020;7:580836.

326. Reuter G, Boros A, Delwart E, Pankovics P. Novel circular single-stranded DNA virus from turkey faeces. Arch Virol. 2014;159(8):2161-4.

327. Lima DA, Cibulski SP, Tochetto C, Varela APM, Finkler F, Teixeira TF, et al. The intestinal virome of malabsorption syndrome-affected and unaffected broilers through shotgun metagenomics. Virus Res. 2019;261:9-20.

328. Duarte MA, Silva JMF, Brito CR, Teixeira DS, Melo FL, Ribeiro BM, et al. Faecal virome analysis of wild animals from Brazil. Viruses. 2019;11(9):803.

329. Liu X, Wang H, Liu X, Li Y, Chen J, Zhang J, et al. Genomic and transcriptional analyses of novel parvoviruses identified from dead peafowl. Virology. 2020;539:80-91.

330. Canuti M, Verhoeven JTP, Munro HJ, Roul S, Ojkic D, Robertson GJ, et al. Investigating the diversity and host range of novel parvoviruses from North American ducks using epidemiology, phylogenetics, genome structure, and codon usage analysis. Viruses. 2021;13(2):193.

331. de Souza WM, Romeiro MF, Fumagalli MJ, Modha S, de Araujo J, Queiroz LH, et al. Chapparvoviruses occur in at least three vertebrate classes and have a broad biogeographic distribution. J Gener Virol. 2017:98(2):225-9.

332. Chong R, Shi M, Grueber CE, Holmes EC, Hogg CJ, Belov K, et al. Fecal Viral Diversity of Captive and Wild Tasmanian Devils Characterized Using Virion-Enriched Metagenomics and Metatranscriptomics. López S, editor. JVirol [Internet]. 2019 Jun [cited 2021];93(11). https://doi.org/ 10.1128/JVI.00205-19

333. Chang W-S, Li C-X, Hall J, Eden J-S, Hyndman TH, Holmes EC, et al. MetaTranscriptomic Discovery of a Divergent Circovirus and a Chaphamaparvovirus in Captive Reptiles with Proliferative Respiratory Syndrome. Viruses. 2020;12(10):1073.

334. Yang S, Liu Z, Wang Y, Li W, Fu X, Lin Y, et al. A novel rodent Chapparvovirus in feces of wild rats. Virol J. 2016:13:133.

335. Ylä-Herttuala S. Endgame: glybera finally recommended for approval as the first gene therapy drug in the European union. Mol Ther. 2012;20(10):1831-2.

336. Patel U, Boucher M, de Léséleuc L, Visintini S. Voretigene Neparvovec: An Emerging Gene Therapy for the Treatment of Inherited Blindness. In: CADTH Issues in Emerging Health Technologies [Internet]. Ottawa (ON): Canadian Agency for Drugs and Technologies in Health; 2016 [cited 2021 Jun 29]. Available from: http://www.ncbi.nlm.nih.gov/books/ NBK538375/

337. Wang D, Tai PWL, Gao G. Adeno-associated virus vector as a platform for gene therapy delivery. Nat Rev Drug Discov. 2019;18(5):358-78.

338. Calcedo R, Vandenberghe LH, Gao G, Lin J, Wilson JM. Worldwide epidemiology of neutralizing antibodies to adeno-associated viruses. J Infect Dis. 2009;199(3):381-90.

339. Bello A, Chand A, Aviles J, Soule G, Auricchio A, Kobinger GP. Novel adeno-associated viruses derived from pig tissues transduce most major organs in mice. Sci Rep. 2015;4(1):6644.

340. Fakhiri J, Schneider MA, Puschhof J, Stanifer M, Schildgen V, Holderbach S, et al. Novel Chimeric Gene Therapy Vectors Based on 
Adeno-Associated Virus and Four Different Mammalian Bocaviruses. Mol Ther Methods Clin Dev. 2019;12:202-22.

341. Kapoor A, Mehta N, Esper F, Poljsak-Prijatelj M, Quan P-L, Qaisar N, et al. Identification and characterization of a new bocavirus species in Gorillas. PLOS ONE. 2010;5(7):e11948.

342. Yu JC, Mietzsch M, Singh A, Jimenez Ybargollin A, Kailasan S, Chipman P, et al. Characterization of the GBoV1 capsid and its antibody interactions. Viruses. 2021;13(2):330.

343. Yan Z, Keiser NW, Song Y, Deng X, Cheng F, Qiu J, et al. A Novel Chimeric Adenoassociated Virus 2/Human Bocavirus 1 Parvovirus Vector Efficiently Transduces Human Airway Epithelia. Mol Ther. 2013;21(12):2181-94.

344. Hartley A, Kavishwar G, Salvato I, Marchini A. A roadmap for the success of oncolytic parvovirus-based anticancer therapies. Annu Rev Virol. 2020;7(1):537-57.

345. Marchini A, Daeffler L, Pozdeev VI, Angelova A, Rommelaere J. Immune conversion of tumor microenvironment by oncolytic viruses: the protoparvovirus H-1PV case study. Front Immunol. 2019;10:1848.

346. Zsak L, Strother KO, Kisary J. Partial genome sequence analysis of parvoviruses associated with enteric disease in poultry. Avian Pathol. 2008;37(4):435-41.

347. Arthur JL, Higgins GD, Davidson GP, Givney RC, Ratcliff RM. A novel bocavirus associated with acute gastroenteritis in Australian children. PLoS Pathog. 2009;5(4):e1000391.

348. Ao Y, Duan Z. Novel primate bocaparvovirus species 3 identified in wild macaca Mulatta in China. Virol Sin. 2020;35(1):34-42.

349. Zeng S, Wang D, Fang L, Ma J, Song T, Zhang R, et al. Complete coding sequences and phylogenetic analysis of porcine bocavirus. J Gener Virol. 2011;92(4):784-8.

350. Lau SKP, Woo PCY, Yip CCY, Li KSM, Fu CTY, Huang Y, et al. Co-existence of multiple strains of two novel porcine bocaviruses in the same pig a previously undescribed phenomenon in members of the family Parvoviridae, and evidence for inter- and intra-host genetic diversity and recombination. J Gener Virol. 2011;92(9):2047-59.
351. Kumar D, Chaudhary S, Lu N, Duff M, Heffel M, McKinney CA, et al. Metagenomic next-generation sequencing reveal presence of a novel ungulate bocaparvovirus in alpacas. Viruses. 2019;11(8):701.

352. Bantel-Schaal U, Zur HH. Characterization of the DNA of a defective human parvovirus isolated from a genital site. Virology. 1984;134(1):52-63.

353. Palya V, Zolnai A, Benyeda Z, Kovács E, Kardi V, Mató T. Short beak and dwarfism syndrome of mule duck is caused by a distinct lineage of goose parvovirus. Avian Pathol. 2009;38(2):175-80.

354. Cossart YE, Field AM, Cant B, Widdows D. Parvovirus-like particles in human sera. Lancet. 1975;1 (7898):72-3.

355. Sasaki M, Gonzalez G, Wada Y, Setiyono A, Handharyani E, Rahmadani I, et al. Divergent bufavirus harboured in megabats represents a new lineage of parvoviruses. Sci Rep. 2016;6(1):24257.

356. Sasaki M, Orba Y, Anindita PD, Ishii A, Ueno K, Hangombe BM, et al. Distinct lineages of bufavirus in wild shrews and Nonhuman primates. Emerg Infect Dis. 2015;21(7):1230-3.

357. Phan TG, Vo NP, Bonkoungou IJO, Kapoor A, Barro N, O'Ryan M, et al. Acute Diarrhea in West African children: diverse enteric viruses and a novel parvovirus genus. J Virol. 2012;86(20):11024-30

358. Handley SA, Thackray LB, Zhao G, Presti R, Miller AD, Droit L, et al. Pathogenic Simian immunodeficiency virus infection is associated with expansion of the enteric virome. Cell. 2012;151(2):253-66.

359. Phan TG, Dreno B, da Costa AC, Li L, Orlandi P, Deng X, et al. A new protoparvovirus in human fecal samples and cutaneous $T$ cell lymphomas (mycosis fungoides). Virology. 2016;496:299-305.

360. Phan TG, Sdiri-Loulizi K, Aouni M, Ambert-Balay K, Pothier P, Deng X, et al. New parvovirus in child with unexplained diarrhea. Tunisia Emerg Infect Dis. 2014;20(11):1911-3.

\section{Publisher's Note}

Springer Nature remains neutral with regard to jurisdictional claims in published maps and institutional affiliations.
Ready to submit your research? Choose BMC and benefit from:

- fast, convenient online submission

- thorough peer review by experienced researchers in your field

- rapid publication on acceptance

- support for research data, including large and complex data types

- gold Open Access which fosters wider collaboration and increased citations

- maximum visibility for your research: over 100M website views per year

At BMC, research is always in progress.

Learn more biomedcentral.com/submissions 